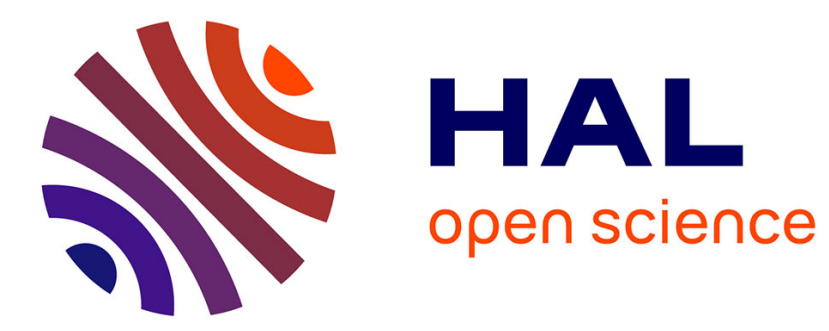

\title{
Predicting the net carbon exchanges of crop rotations in Europe with an agro-ecosystem model
}

\author{
Simon Lehuger, Benoit Gabrielle, Pierre Cellier, Benjamin Loubet, Romain \\ Roche, Pierre Béziat, Eric Ceschia, Martin Wattenbach
}

\section{- To cite this version:}

Simon Lehuger, Benoit Gabrielle, Pierre Cellier, Benjamin Loubet, Romain Roche, et al.. Predicting the net carbon exchanges of crop rotations in Europe with an agro-ecosystem model. 2010. hal$00414342 \mathrm{v} 2$

\section{HAL Id: hal-00414342 \\ https://hal.science/hal-00414342v2}

Preprint submitted on 1 Sep 2010

HAL is a multi-disciplinary open access archive for the deposit and dissemination of scientific research documents, whether they are published or not. The documents may come from teaching and research institutions in France or abroad, or from public or private research centers.
L'archive ouverte pluridisciplinaire HAL, est destinée au dépôt et à la diffusion de documents scientifiques de niveau recherche, publiés ou non, émanant des établissements d'enseignement et de recherche français ou étrangers, des laboratoires publics ou privés. 


\title{
Predicting the net carbon exchanges of crop rotations in Europe with an agro-ecosystem model
}

\author{
S. Lehuger ${ }^{a} 1$, B. Gabrielle ${ }^{b}$, P. Cellier ${ }^{c}$, B. Loubet $^{c}$, R. Roche $^{c}$, P. Béziat ${ }^{d}$, \\ E. Ceschia ${ }^{d}$, M. Wattenbach ${ }^{e}$
}

a: Agroscope Reckenholz-Tänikon Research Station ART, Air pollution/Climate Group, Reckenholzstrasse 191, 8046 Zurich, Switzerland

b: AgroParisTech, UMR 1091 INRA-AgroParisTech Environnement et Grandes Cultures, 78850 Thiverval-Grignon, France

c: Institut National de la Recherche Agronomique, UMR 1091

INRA-AgroParisTech Environnement et Grandes Cultures, 78850

Thiverval-Grignon, France

d: CESBIO, 18 Av. E. Belin, F-31401 Toulouse, France

e: Freie Universitaet Berlin, Institut für Meteorologie,

Carl-Heinrich-Becker-Weg 6-10, 12165 Berlin, Germany

\footnotetext{
${ }^{1}$ Corresponding author: Agroscope Reckenholz-Tänikon Research Station ART, Air pollution/Climate Group, Reckenholzstrasse 191, 8046 Zurich, Switzerland. E-mail: Simon.Lehuger@art.admin.ch. Fax: (+41) 4437772 01. Phone: (+41) 443777513.
} 


\section{Abstract}

Carbon fluxes between croplands and atmosphere are highly conditioned by farmer practices that involved intense atmospheric $\mathrm{CO}_{2}$ uptake during crop growing season compared to other terrestrial ecosystems. Modelling and measuring land-atmosphere carbon exchanges from arable lands are important tasks to predict the influence of vegetation dynamics on climate change and its retroactive effects on crop productivity. We tested the agro-ecosystem model CERES-EGC against gap-filled daily net $\mathrm{CO}_{2}$ exchanges over crop rotations monitored in three arable sites in Europe. The model parameters were estimated using Bayesian calibration and the model prediction accuracy was assessed with two supplementary independent data sets. As a result, the calibrated model allowed us to compute the net ecosystem production (NEP) and net biome production (NBP) for entire crop rotations. The Bayesian calibration method results in an improvement of goodness of fit compared to initial parameter-based simulations. The calibrated model was accurate to estimate the NEP from daily time scale to aggregated NEP for entire crop rotation. The carbon returns from application of organic manure and the carbon uptake from catch crops and crop volunteers generated an important $\mathrm{C}$ sink effect on the NBP. Adding the nitrous oxide and methane fluxes from soils to the $\mathrm{CO}_{2}$ balance will allow us to compute the total greenhouse gas budget of agro-ecosystems.

\section{Keywords}

Carbon dioxide; Agro-ecosystem model; CERES-EGC; Bayesian calibration; Independent validation; Greenhouse gases; Carbon balance; Net Biome Production 


\section{Introduction}

Agriculture contributes about 10-12\% of the global anthropogenic emissions of greenhouse gases (GHGs), a share expected to rise due to an increase in land use and management intensity of agriculture worldwide (Smith et al., 2007). The direct GHG emissions of agro-ecosystems comprise nitrous oxide (2.8 $\mathrm{Gt} \mathrm{CO}_{2}$-eq $\mathrm{yr}^{-1}$ ), methane $\left(3.3 \mathrm{Gt} \mathrm{CO}_{2}\right.$-eq $\left.\mathrm{yr}^{-1}\right)$, their exchanges of $\mathrm{CO}_{2}$

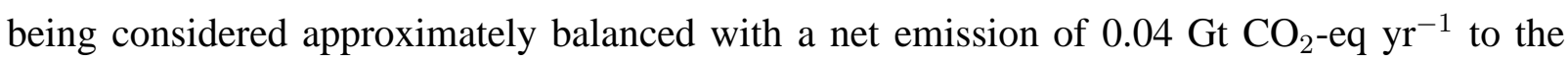
atmosphere (Smith et al, 2007). The net fixation of $\mathrm{CO}_{2}$ by crops and soil respiration are the two main processes by which adapted management practices may increase the potential of $\mathrm{C}$ sequestration in soils (Johnson et al, 2007). The balance of these two terms corresponds to the net ecosystem production (NEP) of carbon, which is a measure of the $\mathrm{C}$ source or sink strength of ecosystems respective to the atmospheric compartment (Smith et al., this issue).

Experimental monitoring of net ecosystem exchange (NEE, NEE=-NEP) have been increasingly carried out using eddy-covariance (EC) techniques, and for all types of managed ecosystems: grasslands (Ammann et al., 2007; Veenendaal et al., 2007), forests (Pilegaard et al., 2001; Kurbatova et al., 2008), and croplands (Moureaux et al., 2006; Anthoni et al., 2004). Their values varied across ecosystem types but also within each class due to pedoclimatic differences and management practices. Croplands are usually characterized by episodes of high $\mathrm{C}$ uptake during the crop growing season, directly related to farmers' management practices. A large part of the fixed $\mathrm{C}$ is removed from the field after harvest, and the residues are returned to the soil and processed by soil microbes.

Accounting the absolute carbon balance of croplands requires the export and import of organic $\mathrm{C}$ within the agricultural field to be taken into consideration. This balance, called the net biome production (NBP), shows a large range of variations between crop species, management intensity and temporal variations at interannual scale. For example, Grant et al. (2007) reported that a 
maize-soybean rotation in Nebraska (USA) was a net C source because of the failure of positive maize NBP to offset negative soybean NBP in the next year. Anthoni et al. (2004) estimated the effect of manure application on NBP, and pointed out that manure largely offsets the C loss in the year of application. They also noticed that $\mathrm{C}$ input in the previous years significantly contributed to the $\mathrm{C}$ exchanges in a given year. Turner et al. (2007) mentioned the strong influence of climate on the interannual variations of the $\mathrm{C}$ budget over a large domain (Oregon state, USA). Accordingly, it appears that croplands may be sources or sinks of $\mathrm{C}$ and that entire crop rotations should be considered to compute the $\mathrm{C}$ balance.

Because the $\mathrm{C}$ balance of croplands is heavily manipulated by farmers, and regulated by environmental conditions, biophysical models that simulate the turnover of $\mathrm{C}$ in agro-ecosystems appear a promising approach to estimate them (Huang et al., 2009). Grant et al. (2007) considered that process-based ecosystem models are the best method to predict net ecosystem production for known or hypothesized management practices or climate and where NEP measurements are incomplete or not available. Complexity, provenance and applications explained the main differences between the modelling approaches of $\mathrm{C}$ exchanges from crops. Carbon models were developed either from agronomic sciences (Agro-C, Huang et al. (2009)), biogeochemical sciences (Ecosys, Grant et al. (2007); DNDC, Zhang et al. (2002)), or for land surface models for use in larger-scale atmospheric models (ORCHIDEE-STICS, Gervois et al. (2008); ChinaAgrosys, Wang et al. (2007); SiBcrop, Lokupitiya et al. (2009)). Eddy-covariance measurements have been widely used for development and testing of the latter category of models, generally known as soil-vegetation-atmosphere transfer (SVAT) models, which couple C to energy and water balances on an hourly (or less) time step. The development of SVAT models against EC data are commonly met in the literature for forest (Klemedtsson et al., 2007; Svensson et al., 2008; Kurbatova et al., 2008; Dufrêne et al., 2005) and cropland ecosystem modelling (Wang et al., 2007; de Noblet-Ducoudré et al., 2004), but most of these model-data comparison studies are 
limited to a maximum of one crop cycle or one year time span. Only a few studies consider the succession of crops in time (Lokupitiya et al., 2009).

Crop growth models developed by agronomists integrate longer timeframes (growing season or crop rotation), and may include more regulators (e.g., $\mathrm{N}$ cycling) and drivers (crop management). They have been widely used to simulate the growth and development of arable crops, and tested against field data collected at weekly or monthly frequencies such as crop dry matter or leaf area index (Zhang et al., 2002), but have rarely been compared to data of daily net $\mathrm{C}$ exchanges. Adiku et al. (2006) were surprised that such measurements had not been amply used before their study for the development and validation of crop gas exchange and growth models. They developed a model for simulating the net carbon exchanges of spring barley and compared its predictions with daily observations of gross primary production over one cropping season. Since their pioneering study, EC measurements have been actively used for SVAT model development and validation but their use is still limited for agronomic crop model development.

In a large number of crop models, crop mass accumulation is estimated with the relationship between plant dry matter and interception of solar radiation. Daily biomass production is usually calculated as the product of the daily cumulative radiation intercepted with the radiation use efficiency (RUE, g DM MJ ${ }^{-1}$ ). Radiation use efficiency is determined by measuring crop growth commonly based on measurements of above-ground biomass without estimating the root compartment (Sinclair and Muchow, 1999). Gabrielle et al. (2002) noticed that low C mineralization fluxes in soil simulated by soil-crop models may be attributed to a strong underestimation of the turnover of belowground plant biomass. The authors advised that much more dry matter should be partitioned to the roots and that RUE should be accordingly increased. Here we assume that calibration of RUE parameters of crop growth sub-models against net $\mathrm{C}$ exchanges would allow us to take into account the whole plant $\mathrm{C}$ fixation integrating the root growth and rhizodeposition. 
Our general objective was to test the capacity of the soil-crop model CERES-EGC to predict daily NEP over crop rotations, using experimental data from arable sites in Europe (part of the CarboEurope measurement network; Moors et al., this issue).

\section{Material and Methods}

We used four different data sets from intensively monitored cropping systems to test the ability of the biophysical CERES-EGC model to simulate $\mathrm{CO}_{2}$ exchanges at the field scale. The experimental sites are located in Grignon (France), Auradé (France) and Gebesee (Germany), and involved different pedoclimatic conditions, crop types and management. At the three sites, net carbon fluxes were measured using the eddy covariance technique following the methodology of the CarboEurope integrated project (Smith et al., this issue). The model was parameterized using a Bayesian calibration method based on the Metropolis-Hastings algorithm Metropolis et al., 1953) against two data sets of daily NEP measurements collected over crop rotations. We also tested the prediction accuracy of the calibrated model with two other independent data sets and finally, we applied the model to compute carbon balances for crop rotations.

\subsection{The CERES-EGC model}

\subsubsection{A process-based agro-ecosystem model}

CERES-EGC was adapted from the CERES suite of soil-crop models (Tones and Kiniry, 1986), with a focus on the simulation of environmental outputs such as nitrate leaching, emissions of $\mathrm{N}_{2} \mathrm{O}$ and nitric oxide (Gabrielle et a1,, 2006). CERES-EGC runs on a daily time step, and requires daily rain, global radiation, maximum and minimum air temperature, wind speed and Penman potential evapo-transpiration as forcing variables. The CERES models are available for a large number of crop species, which share the same soil components (Jones and Kiniry, 1986).

CERES-EGC comprises sub-models for the major processes governing the cycles of water, car- 
bon and nitrogen in soil-crop systems. A physical sub-model simulates the transfer of heat, water and nitrate down the soil profile, as well as soil evaporation, plant water uptake and transpiration in relation to climatic demand. Water infiltrates down the soil profile following a tipping-bucket approach, and may be redistributed upwards after evapo-transpiration has dried some soil layers. In both of these equations, the generalised Darcy's law has subsequently been introduced in order to better simulate water dynamics in fine-textured soils (Gabrielle et al., 1995).

A biological sub-model simulates the growth and phenology of the crops. Crop net photosynthesis is a linear function of intercepted radiation according to the Monteith approach, with interception depending on leaf area index based on Beer's law of diffusion in turbid media. Radiation use efficiency (RUE) is defined for each crop as the dry biomass produced per unit of radiation intercepted by the crop. Photosynthates are partitioned on a daily basis to currently growing organs (roots, leaves, stems, fruits) according to crop development stage. The latter is driven by the accumulation of growing degree days, as well as cold temperature and day-length for crops sensitive to vernalisation and photoperiod. Lastly, crop $\mathrm{N}$ uptake is computed through a supply/demand scheme, with soil supply depending on soil nitrate and ammonium concentrations and root length density.

A micro-biological sub-model simulates the turnover of organic matter in the plough layer. Decomposition, mineralisation and $\mathrm{N}$-immobilisation are modelled with three pools of organic matter (OM): the labile OM, the microbial biomass and the humads. Kinetic rate constants define the $\mathrm{C}$ and $\mathrm{N}$ flows between the different pools. Direct field emissions of $\mathrm{CO}_{2}, \mathrm{~N}_{2} \mathrm{O}, \mathrm{NO}$ and $\mathrm{NH}_{3}$ into the atmosphere are simulated with different trace gas modules.

\subsubsection{Modelling of net carbon exchange}

Carbon dioxide exchanges between soil-plant system and the atmosphere are modelled via the net photosynthesis and soil organic carbon (SOC) mineralization processes. Net primary produc- 
tion (NPP) is simulated by the crop growth modules of the different crop species (wheat, maize, barley, rapeseed and sunflower), while soil heterotrophic respiration (Rs) is deduced from the SOC mineralization rates calculated by the microbiological sub-model as represented in Fig. 1 . The net ecosystem production (NEP), which is calculated as NPP minus Rs, may be computed on a daily basis and directly tested against the net ecosystem exchanges measured by eddy covariance. The comparison between the daily rates of simulated and measured NEP provides a good opportunity to calibrate the parameters related to $\mathrm{CO}_{2}$ flux modelling and to test the simulation of $\mathrm{C}$ dynamics by the ecosystem model. In all sites, a complete rotation was run before the measurement period to stabilize the soil $\mathrm{C}$ and $\mathrm{N}$ pools and dampen the effects of initial conditions. The net biome production was calculated by aggregating daily NEP estimated by simulation or observation over cropping cycles, plus organic manure imports, minus $\mathrm{C}$ exported by harvested biomass.

\subsection{Field sites}

Net ecosystem exchange measurements were carried out with eddy covariance technique at three experimental sites located in Europe: Grignon (northern France, 48.9 N, 1.95 E), Auradé (southern France, 43.5 N, 1.1 E) and Gebesee (Germany, 51.1 N, 10.9 E). The site characteristics and crop rotations are detailed in Table 1 .

The Grignon site is located about $40 \mathrm{~km} \mathrm{~W}$ of Paris, France. The soil was a silt loam with $18.9 \%$ clay and $71.3 \%$ silt in the topsoil and in the top $15 \mathrm{~cm}$, organic carbon content was $20 \mathrm{~g} \mathrm{~kg}^{-1}$, the $\mathrm{pH}$ (water) was 7.6 and the bulk density $1.3 \mathrm{~g} \mathrm{~cm}^{-3}$. In Grignon, two field-sites experiments (NitroEurope, NEU-Grignon and BioPollAtm, BPA-Grignon) were conducted on adjacent plots with the same soil characteristics. The crop rotation of the NEU-Grignon experiment included maize, winter wheat, winter barley and mustard which was planted to serve as a catch crop to reduce nitrate leaching during winter. Dairy cow slurry was applied between the harvest of barley 
and the planting of mustard on 31 August 2004, and before the maize sowing on 16 April 2008. For the BPA-Grignon experiment, NEE measurements were carried during the maize growing season in 2002.

Auradé is located about $30 \mathrm{~km} \mathrm{~W}$ of Toulouse, France. The soil was a clay loam with $30.2 \%$ clay and $48.4 \%$ silt in the top $15 \mathrm{~cm}$, organic carbon was $10 \mathrm{~g} \mathrm{~kg}^{-1}$, the $\mathrm{pH}$ (water) was 6.9 and the bulk density $1.4 \mathrm{~g} \mathrm{~cm}^{-3}$. The Auradé site involved a winter wheat-sunflower-winter wheatrapeseed rotation since at least 2000 .

The Gebesee experimental site is located about $20 \mathrm{~km} \mathrm{NW}$ of Erfurt in Germany. The soil was a Chernozerm (silty clay loam) with $35.8 \%$ clay and $60.3 \%$ silt in the top $20 \mathrm{~cm}$, organic carbon was $23 \mathrm{~g} \mathrm{~kg}^{-1}$, the $\mathrm{pH}$ (water) was 6.7 and the bulk density $1.3 \mathrm{~g} \mathrm{~cm}^{-3}$. The crop sequence from 2003 to 2007 was rapeseed-winter barley-sugar beet-winter wheat. Two applications of organic fertilizers were carried out in 2007, one application of cattle slurry $\left(18 \mathrm{~m}^{3} \mathrm{ha}^{-1}\right)$ in the wheat crop in 11 Apr. and $35 \mathrm{t} \mathrm{ha}^{-1}$ of farmyard manure in 4 Sept.

\section{$2.3 \mathrm{CO}_{2}$ fluxes and biomass measurements}

In all sites, the measurements of $\mathrm{CO}_{2}$ fluxes at the field scale were carried out following the methodology the CarboEurope integrated project (IP) (Aubinet et al., 2000). Water vapour and $\mathrm{CO}_{2}$ fluxes were measured at a 2 to $3 \mathrm{~m}$ height above the crop canopy using the eddy covariance technique. Wind speed was monitored with three-dimensional sonic anemometers, and $\mathrm{CO}_{2}$ concentration with infrared gas analysers (model Li7500 in Grignon and Auradé and model Li7000 in Gebesee; LiCor Inc., Lincoln, NE, USA). Daily NEP of carbon dioxide $\left(\mathrm{g} \mathrm{C} \mathrm{m}^{-2} \mathrm{~d}^{-1}\right)$ and evapotranspiration rate $\left(\mathrm{mm} \mathrm{m}^{-2} \mathrm{~d}^{-1}\right)$ were calculated by integrating the 30 -minute fluxes obtained with the micrometeorological measurements over $24 \mathrm{~h}$ periods. The data sets were processed following the standardised methodology described in Papale et al. (2006). Carbon dioxide fluxes were corrected for $\mathrm{CO}_{2}$ storage below EC measurement height, low turbulence conditions 
were filtered using a friction velocity threshold criterion. The eddy covariance technique and subsequent data processing produce gaps in the half-hourly $\mathrm{C}$ flux data, making it necessary to fill the missing values before integration at the daily time scale. The gap-filling methodology of CarboEurope-IP was applied to the experimental data sets (Falge et al., 2001).

Above-ground plant dry matter (DM) was measured every two weeks during crop growth, over the full crop sequences of the Auradé, NEU-Grignon and BPA-Grignon experiments. Daily weather data were recorded with automatic meteorological station, including maximum and minimum daily air temperatures $\left({ }^{\circ} \mathrm{C}\right)$, rainfall $\left(\mathrm{mm} \mathrm{d}^{-1}\right)$, solar radiation $\left(\mathrm{MJ} \mathrm{m}^{-2} \mathrm{~d}^{-1}\right)$ and wind speed $\left(\mathrm{m} \mathrm{s}^{-1}\right)$ at each site and they were used as model inputs for the model simulations.

\subsection{Parameter calibration}

The parameters were estimated using the Bayesian calibration method described in Lehuger et al. (2009). Table 2 lists the parameters involved in the calibration as well as their prior probability density functions (pdf). Briefly, Bayesian methods are used to estimate model parameters by combining two sources of information: prior information about parameter values and observations of model output variables. In our case, the observations consisted of the NEP measurements. Bayes' theorem makes it possible to combine the two sources of information in order to calibrate the model parameters. The first step is to assign a probability distribution to the parameters, representing our prior uncertainty about their values. We specified lower and upper bounds for the uncertainty of the parameters, and defined the prior pdfs as uniform (Table 2). The aim of Bayesian calibration is to reduce this uncertainty by using measured data, thereby producing the posterior distribution for the parameters. This is achieved by multiplying the prior with the likelihood function, which is the probability of the data given the parameters. Because probability densities may be very small numbers, rounding errors needed to be avoided and all calculations were carried out using logarithms. The logarithm of the data likelihood is thus set 
up, for each data set $\mathrm{D}_{i}$, as follows:

$$
\log L_{i}=\sum_{j=1}^{K}\left(-0.5\left(\frac{y_{j}-f\left(\omega_{k} ; \theta_{l}\right)}{\sigma_{j}}\right)^{2}-0.5 \log (2 \pi)-\log \left(\sigma_{j}\right)\right)
$$

where $\mathrm{y}_{j}$ is the NEP measured on sampling date $\mathrm{j}$ in the data set $\mathrm{D}_{i}$, and $\sigma_{j}$ the standard deviation, $\omega_{k}$ is the vector of model input data for the same date, $f\left(\omega_{k} ; \theta_{l}\right)$ is the model simulation of $\mathrm{y}_{j}$ with the parameter vector $\theta_{l}$, and $\mathrm{K}$ is the total number of observation dates in the data sets. Two additional parameters were involved in the calibration, corresponding to a site-specific experimental error of NEE measurements. Parameters psys 1 for systematic error of measurement in NEU-Grignon and psys2 for Auradé were introduced in the log-likelihood function as multiplicative factors of $\mathrm{D}_{i}$. We defined their prior pdfs as uniform over the [0.5-2] range. To generate a representative sample of parameter vectors from the posterior distribution, we used a Markov Chain Monte Carlo (MCMC) method: the Metropolis-Hastings algorithm (Metropolis et al., 1953). We formed Markov chains of length $10^{4}-10^{5}$ using a multivariate Gaussian pdf to generate candidate parameter vectors. The variance matrix of this Gaussian was adjusted to ensure an efficient exploration of the parameter space by the Markov chains. We first set the marginal variances to the square of $1 \%$ of the prior parameter ranges, and the covariances to zero (Van Oijen et al., 2005). In addition, the acceptance rate was artificially adjusted by increasing the measurement uncertainty in order to smoothe the likelihood surface and make the calibration easier. Due to the large amount of observed data involved, the likelihood surface presented sharp peaks and the probability for the model to hit a 'target area' for a successful calibration was too small otherwise. Ten percent of the total number of iterations at the beginning of the chain were discarded as unrepresentative 'burn-in' segments of the chains (Van Oijen et al. 2005). The rest of the chains were considered as a representative sample from the posterior pdf, and were used to calculate the mean vector, the variance matrix and the $90 \%$ confidence interval for each parameter. Bayesian calibration was successively applied to the Auradé experiment and the 
NEU-Grignon treatment.

\subsection{Goodness of fit}

The goodness of fit between simulations and observations was assessed by calculating the root mean square error (RMSE). The RMSE was used to judge the performance of the parameter calibration as well as the model prediction error for the two independent data sets. It was calculated for each data set $\mathrm{D}_{i}$ as follows (Wallach, 2006):

$$
R M S E=\sqrt{\frac{1}{K} \sum_{j=1}^{K}\left(y_{j}-f\left(\omega_{k} ; \theta_{l}\right)\right)^{2}}
$$

where $\mathrm{y}_{j}$ is the observed NEP on day $\mathrm{j}$ of data set $\mathrm{D}_{i}$, and $\mathrm{f}\left(\omega_{k} ; \theta_{l}\right)$ is the corresponding model predictions with input variables $\omega_{k}$ and parameters $\theta_{l}$. Simulations were carried out using either the posterior expectancy of parameters $\left(\overline{\theta_{l}}\right)$ or the maximum a posteriori (MAP) estimate of $\theta$ $\left(\theta_{M A P, l}\right) . \theta_{M A P}$ is the single best value of the parameter vector in MCMC chain, which maximizes the posterior probability density (Van Oijen et al., 2005). The posterior expectancy of predictions were obtained from the posterior parameter pdfs. The root mean square errors were computed for the experiments used in the parameter calibration (NEU-Grignon and Auradé) and in the subsequent model testing against independent data sets (BPA-Grignon and Gebesee). In the latter case, the RMSE corresponded to the root mean squared error of prediction $(\operatorname{RMSEP}(\theta))$, since the data were involved neither in parameter estimation nor model development Wallach, 2006). RMSEP is a measure of the model's accuracy in the prediction of NEP.

\section{Results}

\subsection{Model calibration}

Table 2 shows the mean and standard deviations of the posterior parameter distributions obtained after calibration against the NEU-Grignon and Auradé data sets. The posterior radiation use effi- 
ciencies (RUEs) of maize and wheat were lower than their default values for both sites, by $30 \%$ for maize, and $15 \%$ to $30 \%$ for wheat. Thus, the uncalibrated wheat and maize crop components of CERES-EGC tended to overestimate crop biomass. Conversely, the calibrated RUEs of rapeseed and sunflower were lower or higher than their initial values, depending on development phase and experimental site.

The posterior parameter values of SOC mineralization parameters were generally close to their default values except for the parameters prop1, prop2, cfres 1 and cfres2 (Table 2). The decomposition rate of residue carbohydrate pool (cfres1) was substantially increased for calibration against Auradé data set ( 0.61 vs. $\left.0.20 \mathrm{~d}^{-1}\right)$ and slightly increased for calibration against NEUGrignon data set $\left(0.29\right.$ vs. $\left.0.20 \mathrm{~d}^{-1}\right)$. The coefficients partitioning endogenous soil organic $\mathrm{C}$ into the microbial biomass (prop1) and humads (prop2) pools were also higher than their default values, respectively $60 \%$ for prop 1 in NEU-Grignon and $75 \%$ for prop 2 in Auradé. The parameters psys 1 and psys 2 were calibrated within the Bayesian calibration at the same time as the model parameters and their mean posterior values were $1.38( \pm 0.26)$ and $0.87( \pm 0.20)$ for NEUGrignon and Auradé respectively. This result means that the measurements in NEU-Grignon would be underestimated whereas they would be overestimated in Auradé.

Table 3 summarizes the RMSEs for daily and cumulative NEP, and above-ground plant biomass obtained with the various parameter sets (prior and posterior). The calibration led to a $15 \%$ to $30 \%$ reduction of the RMSE relative to the uncalibrated parameter set. There were small differences between the RMSEs computed with posterior expectancy of parameters and posterior expectancy of predictions. The simulations computed with the parameter set with maximum posterior probability, i.e. when likelihood is maximal, involved RMSE values for daily NEP lower than RMSEs computed with posterior expectancy of parameters. On the other hand, this parameter set involved higher RMSE values for the cumulative sum of NEP and aboveground (ABG) biomass in Auradé, compared to the RMSEs computed with posterior expectancy of prediction 
and posterior expectancy of parameters.

\subsection{Dynamics of net carbon exchanges}

Figure 2 (a and d) compares the simulations of daily NEP after calibration and the observations for the crop rotations of the NEU-Grignon and Auradé experiments. There was good agreement between the two series at the time scale of a growing season (from sowing to harvest), and also for the time intervals in between two crops. The growing seasons of spring crops (maize and sunflower) were shorter than those of winter crops (rapeseed, wheat, barley), but simulations of daily $\mathrm{C}$ uptake reached higher values for maize and sunflower. The net carbon exchanges reached a peak value of $15 \mathrm{~g} \mathrm{C} \mathrm{m}^{-2} \mathrm{~d}^{-1}$ for the maize crop in Grignon, while they did not exceed $10 \mathrm{~g} \mathrm{C} \mathrm{m}^{-2} \mathrm{~d}^{-1}$ with winter crops. The net fixation of $\mathrm{C}$ was directly related to global solar radiation, which led to irregular patterns of net photosynthesis. Crop residues, senescent roots and the application of organic manure fed the fresh organic matter pool of soil and were slowly decomposed after incorporation in soil. Soil respiration mainly occurred in autumn and winter following the incorporation of crop residues in soil, with daily rates ranging between -5 and $0 \mathrm{~g} \mathrm{C} \mathrm{m}^{-2} \mathrm{~d}^{-1}$.

In Grignon, after the harvest of barley crops in years 2004 and 2007, mustard was planted as a catch crop. Its growth was well simulated in 2008 , whereas in 2004 , the simulated time span of crop growth and net $\mathrm{C}$ fixation was shorter than observed. As a result, the total $\mathrm{C}$ fixation by the mustard was underestimated in 2004 by the model, as was that of the maize crop in 2008 (Fig. 2.c).

In Auradé, no catch crop was sown after the harvests of rapeseed in 2005 and wheat in 2006, but volunteers of previous crops grew up and entailed a net $\mathrm{C}$ uptake. This effect was modelled by resowing the same crop after harvest and stopping its growth upon tillage. Net ecosystem production was remarkably well predicted during the rapeseed and wheat growing seasons, but 
it was overestimated over the sunflower crop. This was due to the model underestimation of soil respiration rates in the months preceding the sowing of sunflower.

Figures 2.b and 2. Grignon and Auradé. The coefficients of determination were fairly good, with an $\mathrm{R}^{2}$ of 0.76 and 0.59 in Grignon and Auradé, respectively. There was also little systematic error in the predictions: the slope of the regressions was equal to unity (Grignon) or close to this value $(0.82)$ in Auradé, and the intercepts were negligible (0.25 and $0.00 \mathrm{~g} \mathrm{C} \mathrm{m}^{-2} \mathrm{~d}^{-1}$ in Grignon and $\mathrm{Au}-$ radé, respectively). When cumulated over the measurement period, net $\mathrm{C}$ fluxes were correctly predicted by the model for the NEU-Grignon and Auradé experiments (Fig. 21.c and 2.e), which proves its capacity to integrate the various $\mathrm{C}$ fluxes and turnover rates within the agro-ecosystem. The simulations of above-ground biomass of crops were also well within the measurement errors (Fig. 3.a and 3.c), for the various crop species, with the exception of the 2008 maize upon harvest in Grignon, whose dry matter was under-predicted. The regression analysis evidenced a good match between observed and simulated data (after calibration). For the NEU-Grignon experiment, we obtained an $\mathrm{R}^{2}$ of 0.95 , an intercept of $-0.75 \mathrm{t} \mathrm{DM} \mathrm{ha} \mathrm{D}^{-1}$ and a slope of 1.2 , and for Auradé, an $\mathrm{R}^{2}$ of 0.94 , an intercept of $0.35 \mathrm{t} \mathrm{DM} \mathrm{ha}^{-1}$ and a slope of 1.12. Six different crop species, involving 6 crop-specific sub-models, were involved in the rotations but did not hamper a good match to the field-measurements.

\subsection{Model performance}

The experiments of Gebesee and BPA-Grignon were used to assess the model prediction accuracy by computing the RMSEP, after calibration against the data from the NEU-Grignon trial (Table 4 . The field experiments used in model testing represented different climate and soil conditions compared to the calibration sites, with similar crop management. The RMSEP for daily NEP was lower for the wheat in Gebesee than for the maize in BPA-Grignon, amounting 
to 1.55 and $3.78 \mathrm{~g} \mathrm{C} \mathrm{m}^{-2} \mathrm{~d}^{-1}$, respectively. Conversely, the RMSEP for cumulative NEP was 3 times lower for BPA-Grignon than for Gebesee, being respectively 31.61 and $90.95 \mathrm{~g} \mathrm{C} \mathrm{m}^{-2}$. The RMSEP of ABG biomass was computed only for BPA-Grignon due to a lack of biomass measurements in Gebesee. Figures $\bigoplus$.a and $\sharp$.d depicts the dynamics of daily NEP for Gebesee and BPA-Grignon. At Gebesee, the model accurately captured the dynamics of net $\mathrm{C}$ fixation by the crop and the post-harvest soil respiration. In the BPA-Grignon trial, the measurement period was focused on the maize growing season, and the spike of net $\mathrm{C}$ fixation measured in July was not captured by the model. The radiation use efficiency of maize calibrated with the NEU-Grignon dataset appeared suboptimal for the BPA-Grignon experiment. The regressions between observed and simulated daily NEP were satisfactory overall, with an $\mathrm{R}^{2}$ of 0.49 and 0.79 in Grignon and Gebesee, respectively, while the slopes ranged from 0.77 to 0.88 , and the intercepts ranged from -0.37 to $0.79 \mathrm{~g} \mathrm{C} \mathrm{m}^{-2} \mathrm{~d}^{-1}$ (Figs $\sharp$.b and $\sharp$.e). The relatively low $\mathrm{R}^{2}$ for the BPA-Grignon experiment stems from the model failing to mimic the peak $\mathrm{C}$ fixation fluxes in July, probably because it overestimated the effect of water stress on photosynthesis. The model overestimated the cumulative sum of NEP in Gebesee whereas it slightly underestimated this variable in BPA-Grignon (Figs 甘.c and Ð.f).

Figure 5 depicts the time course of ABG dry matter for the maize crop of the BPA-Grignon experiment. Simulations were computed either with the posterior expectancy of parameters derived from the calibration of NEU-Grignon or with the initial (uncalibrated) parameter values. Surprisingly, the latter resulted in a more accurate simulation of crop biomass accumulation than the calibrated parameters. On the basis of these results, it appears that the calibration improved the simulation of NEP but without improving the prediction of biomass accumulation. As a result, the RMSEP for ABG biomass with calibrated model was quite high (Table 4 ). 


\subsection{Carbon balance of crop rotations}

Figure 6 shows the time course of carbon balance in all sites, as broken down across crops during the time period extending from their sowing to the sowing of the following crop. In the NEUGrignon experiment, NPP was higher for the 2006 winter wheat and 2007 barley than for the 2005 and 2008 maize crops. On the other hand, soil respiration after winter wheat and barley were higher than for maize crops due to a longer period of net soil respiration from harvest to sowing. As a result, NEP was higher for maize than for winter cereals, averaging 4770 and $4090 \mathrm{~kg} \mathrm{C} \mathrm{ha}{ }^{-1}$, respectively. The mustard sown in 2004 was a net source of $\mathrm{CO}_{2}$, i.e. its net photosynthesis was lower than the net soil respiration. This pattern was reversed with the mustard sown in 2008, which was overall a net sink of $\mathrm{CO}_{2}$. In both cases, the introduction of a catch crop between winter cereals and the following spring crop increases ecosystem uptake of $\mathrm{C}$ at the rotation scale.

In Auradé, seasonal net photosynthesis, soil respiration and net ecosystem production were similar for the 2005 winter rapeseed crop and the 2006 winter wheat (Fig. 6.b), resulting in a NEP (equivalent to a net $\mathrm{C}$-uptake by the ecosystem) of $2800 \mathrm{~kg} \mathrm{C} \mathrm{ha}^{-1}$. The net photosynthesis of sunflower was underestimated by the model, resulting in a NEP lower than for winter crops $\left(1600 \mathrm{~kg} \mathrm{C} \mathrm{ha}^{-1}\right)$. In Gebesee, the net photosynthesis of winter wheat reached $6230 \mathrm{~kg} \mathrm{C} \mathrm{ha}^{-1}$, soil respiration totaled $-4000 \mathrm{~kg} \mathrm{C} \mathrm{ha}^{-1}$ and net ecosystem production $2230 \mathrm{~kg} \mathrm{Cha}^{-1}$ (Fig. 6.c). In this site, soil organic carbon was higher than that in the other sites, generating higher soil respiration rates. In the BPA-Grignon experiment, the net ecosystem production of maize totaled $6490 \mathrm{~kg} \mathrm{C} \mathrm{ha}^{-1}$ over the growing season, corresponding to the balance between net photosynthesis (7740 $\left.\mathrm{kg} \mathrm{C} \mathrm{ha}^{-1}\right)$ and soil respiration (-1250 $\mathrm{kg} \mathrm{C} \mathrm{ha}^{-1}$ - Fig. 6.c).

Table 5 summarizes the modelled and observed carbon inputs and exports for the 4 experiments, by crop. As in the previous section, the $\mathrm{C}$ budget for each crop started upon sowing and ended upon sowing of the following crop, except for Auradé, Gebesee and BPA-Grignon where the 
starting date was the first day of measurement. In the NEU-Grignon experiment, the model predicted the 3-yr rotation to be a net sink of $215 \mathrm{~kg} \mathrm{C} \mathrm{ha}^{-1}$ whereas the observations indicated a net source of $\mathrm{C}\left(-1520 \mathrm{~kg} \mathrm{C} \mathrm{ha}^{-1}\right.$ over the three years). This discrepancy was due to the underestimation of $\mathrm{C}$ fixation by the 2005 maize crop and the amount of straw removed after winter wheat in 2006. In this site, the straw of winter wheat and barley was harvested, whereas in the other sites it was incorporated into the soil. The experimental determination of straw removal rate may also have led to an overestimation of this term, since losses probably occurred upon harvest. The simulated year-round NEP for the year 2005 at NEU-Grignon (encompassing the maize cropping cycle) was $4350 \mathrm{~kg} \mathrm{C} \mathrm{ha}^{-1} \mathrm{yr}^{-1}$ (vs. $3120 \mathrm{~kg} \mathrm{C} \mathrm{ha}^{-1} \mathrm{yr}^{-1}$ observed) and was $5200 \mathrm{~kg} \mathrm{C} \mathrm{ha}^{-1} \mathrm{yr}^{-1}$ for the year 2002 at BPA-Grignon.

In Gebesee, cattle slurry and farmyard manure were applied in 2007 during the winter wheat growing season, making this crop cycle a large C sink. The simulated year-round NEP for 2007 (encompassing a part of the wheat cropping cycle) was $2400 \mathrm{~kg} \mathrm{C} \mathrm{ha}^{-1} \mathrm{yr}^{-1}$, which is much higher than the total of $1133 \mathrm{~kg} \mathrm{C}^{-1}$ measured from 1 Jan. 2007 to 5 Oct. 2007 (the end of measurement period).

In Auradé, we overestimated the $\mathrm{C}$ sink of the rotation 2005-2007 as compared with the observations, 2270 vs. $500 \mathrm{~kg} \mathrm{C}$ ha $^{-1}$ over 2.5 years which is due to a $30 \%$ underestimation of rapeseed grain yield in 2005 and an overestimation of NEP for rapeseed and winter wheat by 10 and 35\% respectively as compared with observations. In the BPA-Grignon experiment, the model underestimated harvested biomass by $40 \%$ which induced a large bias in NBP: 25 vs. $2575 \mathrm{~kg} \mathrm{C} \mathrm{ha}{ }^{-1}$ over 117 days. 


\section{Discussion}

\subsection{Model calibration and prediction error}

Our goal was to parameterise the agro-ecosystem model CERES-EGC in order to estimate the daily NEP over crop rotations, assuming that the calibration against daily NEP data would simultaneously improve the predictions of net ecosystem production, crop growth and carbon balance at rotation scale.

We originally assumed that the calibration of crops' radiation use efficiencies (RUE) against net C exchanges would allow us to take into account whole-plant $\mathrm{C}$ fixation rates, including the belowground growth and turnover, leading to increased RUE values. However, in practice RUEs were substantially reduced after calibration for maize and wheat. As a result, the simulation of $\mathrm{ABG}$ and harvested biomass was underestimated for maize at NEU and BPA-Grignon sites. A possible explanation for such contradictory results could be that the calibration variable was the balance between net $\mathrm{C}$ fixation and heterotrophic respiration, which makes it impossible to properly calibrate both processes independently. Calibrating each process separately with their specific measured data may help in better estimating the RUEs and soil respiration rates. The main limitation is that it is difficult to measure separately the $\mathrm{C}$ fluxes from soil and plant compartments, especially for roots.

In order for the calibration algorithm to converge, we had to artificially increase the measurement uncertainty to smoothe the likelihood surface. The large number of daily observations in our sample (several hundreds of data points) led to a sharply peaked likelihood which is difficult to reach and explore by traditional Metropolis-Hastings algorithm. Processing the data in weekly or monthly means would help in reducing the amount of information and thus it would improve the calibration process. Using an adaptive MCMC sampling algorithm, such as developed by Haario et al. (2001), could also help in adapting the proposal distribution and in optimising 
MCMC algorithm. Bayesian calibration was applied on daily NEP data, making the assumption that if daily values were well simulated the cumulative sum would also be well estimated. This assumption could be questioned and we could compare a calibration against NEP data cumulated for cropping cycles with daily NEP. The processing of data and time length of summary statistics (daily, weekly..) would then depend on the goal to which the model is applied.

The Bayesian calibration on the NEU-Grignon and Auradé experiments resulted in a slight reduction of RMSE compared to the initial parameterization. There was also a close correlation between observed and modelled NEP on daily or seasonal basis, indicating a good capacity of the model to predict NEP at both scales. The coefficients of determination $\left(\mathrm{R}^{2}\right)$ we obtained ranged from 0.59 to 0.76 , and compared well to literature. Huang et al. (2009) reported an $\mathrm{R}^{2}$ of 0.43 when simulating two years of NEP data over an arable field in China with an agro-ecosystem model. Wang et al. (2005) parameterised an ecosystem model against NEP measurements over a wheat-maize sequence in China, and obtained $\mathrm{R}^{2}$ between 0.74 and 0.76 , in the range we obtained in the NEU-Grignon experiment.

After calibration, we estimated the model prediction error (RMSEP) using independent data sets from two experiments with similar crop management but different soil or climate conditions (BPA-Grignon and Gebesee). The RMSEP ranged between 1.5 and $3.8 \mathrm{~g} \mathrm{C} \mathrm{m}^{-2} \mathrm{~d}^{-1}$, indicating a good capacity of CERES-EGC to capture NEP at daily and seasonal scales, and were 4 to 7 times lower than the value of $11.3 \mathrm{~g} \mathrm{C} \mathrm{m}^{-2} \mathrm{~d}^{-1}$ reported by Huang et al. (2009). However, the crop growth at BPA-Grignon was not well simulated because the RUE parameter for maize, calibrated against NEU-Grignon dataset, was not accurate for the maize crop of the BPA-Grignon field site experiment. 


\subsection{Using a crop model to simulate the net carbon exchanges}

Net biome production is very sensitive to the estimation of biomass removal from the field and organic manure inputs. Our model predicted the crop rotations of NEU-Grignon and Auradé to be a net sink. While the modelled estimates of NEP were in agreement with observations, those for grain yields and straw removal rates were lower than observed, which had a large effect on the final $\mathrm{C}$ balances. However, the observations of straw removal in the NEU-Grignon experiment were relatively uncertain since they were based on destructive sampling of plants prior to harvest, and did not take harvest losses or cutting height into account. The differences in the modelled and measured $\mathrm{C}$ balances should therefore be mitigated, considering the potentially large experimental error on the removal terms.

Carbon input from the application of organic fertilizers has an important effect on NBP, reducing it by 50 to $115 \%$ in case of the NEU-Grignon rotation. Carbon uptake from catch crops and volunteers also results in significant inputs of $\mathrm{C}$ into the cropping system. Promoting such management practices that enhance the NBP could help in decreasing the GHG balance of cropping systems.

In Gebesee, the modelled NEP for the year 2007 (2400 $\mathrm{kg} \mathrm{C} \mathrm{ha}^{-1} \mathrm{yr}^{-1}$ ) was higher than 1710$2030 \mathrm{~kg} \mathrm{C} \mathrm{ha}^{-1} \mathrm{yr}^{-1}$, the range reported by Anthoni et al. (2004) and based on measurements for the same site in 2001 for winter wheat. Anthoni et al. (2004) reported that when they removed harvested $\mathrm{C}$ (grain only) from the NEP, the site became a net source of $\mathrm{CO}_{2}$ (of $970 \mathrm{~kg} \mathrm{C} \mathrm{ha}{ }^{-1} \mathrm{yr}^{-1}$ ), whereas we modelled for the year 2007 a NBP of $305 \mathrm{~kg} \mathrm{C} \mathrm{ha}^{-1} \mathrm{yr}^{-1}$ when discounting harvested grain biomass and $4765 \mathrm{~kg} \mathrm{C} \mathrm{ha}^{-1} \mathrm{yr}^{-1}$ when adding the manure application. The authors also simulated the $\mathrm{C}$ exchanges using the process-based models RothC (Coleman et al., 1997) and DNDC (Li et al., 1994) and mentioned that the measurements of carbon losses were higher by a factor of two or more than the simulations. They made two assumptions to explain the gap between simulated and observed data : significant amounts of soil 
organic $\mathrm{C}$ could be mineralized by processes which were not considered in the models or the ecosystem respiration measurements were largely overestimated. Our simulations also corroborated these assumptions for the year 2007.

Our agro-ecosystem model simulates water, $\mathrm{C}$ and $\mathrm{N}$ cycling and GHG fluxes as well as the drivers controlling plant and microbial processes. Simulating net carbon exchanges and crop productivity for various crop species requires a combination of a large number of processes. In particular special attention should be focused on simulating accurate crop phenology (date of harvest), water and $\mathrm{N}$ stress on crop growth, and the partitioning of crop biomass between harvest and soil return.

\section{Conclusion}

We applied a Bayesian method to calibrate the CERES-EGC model against two data sets of NEP from contrasted pedoclimatic conditions and crop sequences (NEU-Grignon and Auradé). The calibrated model allows us to predict the net carbon exchanges between soil-crop and atmosphere from daily to rotation time-scale. We computed the error of model prediction by comparing simulations and observations of NEP from two other independent data sets (BPA-Grignon and Gebesee). The model correctly predicted NEP in both sites, but underestimated crop biomass in one of them.

The originality of our approach is that it computes the various terms of the ecosystems's C balance over entire crop rotations, making it possible to allocate source and sink terms evenly across the crops of the rotation. For instance, the sum of net ecosystem production and $\mathrm{C}$ imports minus the exports, which corresponds to the field-gate balance, could be introduced into the life-cycle GHG budget of agricultural products, as recommended by Rabl et al. (2007). The fate of the C contained in harvested products and used as food, feed or bioenergy could also be accounted, whether the $\mathrm{C}$ is respired and released to the atmosphere as $\mathrm{CO}_{2}$ or returned to 
soils as organic manure. Designing management practices and value-chains that enhance crop C fixation, $\mathrm{C}$ stabilization in soil organic matter and maximize $\mathrm{C}$ returns via manure inputs should help mitigate the net GHG emissions of agro-ecosystems.

\section{Acknowledgments}

This work was part of the CarboEurope and NitroEurope Integrated Projects (EU's Sixth Framework Programme for Research and Technological Development), which both investigate the European terrestrial greenhouse gas balance. We express special thanks to A. Freibauer and W. Kutsch (Max Plank Institute, Jena) for making available the data from Gebesee.

\section{References}

Adiku, S. G. K., Reichstein, M., Lohila, A., Dinh, N. Q., Aurela, M., Laurila, T., Lueers, J., and Tenhunen, J. D. (2006). PIXGRO: A model for simulating the ecosystem $\mathrm{CO}_{2}$ exchange and growth of spring barley. Ecol. Model., 190(3-4):260-276.

Albrizio, R. and Steduto, P. (2005). Resource use efficiency of field-grown sunflower, sorghum, wheat and chick-pea I. Radiation use efficiency. Agr. Forest Meteorol., 130(3-4):254-268.

Ammann, C., Fléchard, C. R., Leifeld, J., Neftel, A., and Fuhrer, J. (2007). The carbon budget of newly established temperate grassland depends on management intensity. Agr. Ecosys. Environ., 121(1-2):5-20.

Andrade, F. H., Uhart, S. A., and Cirilo, A. (1993). Temperature Affects Radiation Use Efficiency in Maize. Field Crop. Res., 32(1-2):17-25.

Anthoni, P. M., Knohl, A., Rebmann, C., Freibauer, A., Mund, M., Ziegler, W., Kolle, O., and 
Schulze, E. D. (2004). Forest and agricultural land-use-dependent $\mathrm{CO}_{2}$ exchange in Thuringia, Germany. Glob. Change Biolo., 10(12):2005-2019.

Aubinet, M., Grelle, A., Ibrom, A., Rannik, U., Moncrieff, J., Foken, T., Kowalski, A. S., Martin, P. H., Berbigier, P., Bernhofer, C., Clement, R., Elbers, J., Granier, A., Grunwald, T., Morgenstern, K., Pilegaard, K., Rebmann, C., Snijders, W., Valentini, R., and Vesala, T. (2000). Estimates of the annual net carbon and water exchange of forests: The EUROFLUX methodology. Adv. Ecol. Res., 30:113-175.

Choudhury, B. J. (2000). A sensitivity analysis of the radiation use efficiency for gross photosynthesis and net carbon accumulation by wheat. Agr. Forest Meteorol., 101(2-3):217-234.

Choudhury, B. J. (2001). Modeling radiation- and carbon-use efficiencies of maize, sorghum, and rice. Agr. Forest Meteorol., 106(4):317-330.

Coleman, K., Jenkinson, D. S., Crocker, G. J., Grace, P. R., Klir, J., Korschens, M., Poulton, P. R., and Richter, D. D. (1997). Simulating trends in soil organic carbon in long-term experiments using RothC-26.3. Geoderma, 81(1-2):29-44.

Corbeels, M., Hofman, G., and Van Cleemput, O. (1999). Simulation of net N immobilisation and mineralisation in substrate-amended soils by the NCSOIL computer model. Biol. Fert. Soils, 28(4):422-430.

de Noblet-Ducoudré, N., Gervois, S., Ciais, P., Viovy, N., Brisson, N., Seguin, B., and Perrier, A. (2004). Coupling the soil-vegetation-atmosphere-transfer scheme ORCHIDEE to the agronomy model STICS to study the influence of croplands on the european carbon and water budgets. Agronomie, 24(6-7):397-407.

Dou, Z. and Fox, R. H. (1995). Using NCSWAP to simulate seasonal nitrogen dynamics in soil and corn. Plant Soil, 177(2):235-247. 
Dufrêne, E., Davi, H., Francois, C., le Maire, G., Le Dantec, V., and Granier, A. (2005). Modelling carbon and water cycles in a beech forest Part I: Model description and uncertainty analysis on modelled NEE. Ecol. Model., 185(2-4):407-436.

Falge, E., Baldocchi, D., Olson, R., Anthoni, P., Aubinet, M., Bernhofer, C., Burba, G., Ceulemans, G., Clement, R., Dolman, H., Granier, A., Gross, P., Grunwald, T., Hollinger, D., Jensen, N. O., Katul, G., Keronen, P., Kowalski, A., Lai, C. T., Law, B. E., Meyers, T., Moncrieff, J., Moors, E., Munger, J. W., Pilegaard, K., Rannik, U., Rebmann, C., Suyker, A., Tenhunen, J., Tu, K., Verma, S., Vesala, T., Wilson, K., and Wofsy, S. (2001). Gap filling strategies for long term energy flux data sets. Agr. Forest Meteorol., 107(1):71-77.

Gabrielle, B., Da-Silveira, J., Houot, S., and Francou, C. (2004). Simulating urban waste compost effects on carbon and nitrogen dynamics using a biochemical index. J. Environ. Qual., 33(6):2333-2342.

Gabrielle, B., Denoroy, P., Gosse, G., Justes, E., and Andersen, M. N. (1998). Development and evaluation of a CERES-type model for winter oilseed rape. Field Crop. Res., 57(1):95-111.

Gabrielle, B., Laville, P., Duval, O., Nicoullaud, B., Germon, J. C., and Hénault, C. (2006). Process-based modeling of nitrous oxide emissions from wheat-cropped soils at the subregional scale. Global Biogeochem. Cycles, 20(4).

Gabrielle, B., Mary, B., Roche, R., Smith, P., and Gosse, G. (2002). Simulation of carbon and nitrogen dynamics in arable soils: a comparison of approaches. Eur. J. Agron., 18(1-2):107120.

Gabrielle, B., Menasseri, S., and Houot, S. (1995). Analysis and field-evaluation of the CERES models water-balance component. Soil Sci. Soc. Am. J., 59(5):1403-1412. 
Gervois, S., Ciais, P., de Noblet-Ducoudré, N., Brisson, N., Vuichard, N., and Viovy, N. (2008). Carbon and water balance of European croplands throughout the 20th century. Global Biogeochem. Cycles, 22(2).

Godwin, D. C. and Jone, A. J. (1991). Nitrogen Dynamics in Soil-Plant Systems. In Hanks, J. and Ritchie, J. T., editor, Modelin Plant and Soil Systems, chapter 13. Agronomy Monograph n³1.

Grant, R. F., Arkebauer, T. J., Dobermann, A., Hubbard, K. G., Schimelfenig, T. T., Suyker, A. E., Verma, S. B., and Walters, D. T. (2007). Net Biome Productivity of Irrigated and Rainfed Maize Soybean Rotations: Modeling vs. Measurements. Agron. J., 99(6):1404-1423.

Haario, H., Saksman, E., and Tamminen, J. (2001). An adaptive Metropolis algorithm. Bernoulli, $7(2): 223-242$

Hadas, A., Feigenbaum, S., Sofer, M., Molina, J. A. E., and Clapp, C. E. (1993). Decomposition of nitrogen-15-labeled wheat and cellulose in soil - modeling tracer dynamics. Soil Sci. Soc. Am. J., 57(4):996-1001.

Henriksen, T. M. and Breland, T. A. (1999). Nitrogen availability effects on carbon mineralization, fungal and bacterial growth, and enzyme activities during decomposition of wheat straw in soil. Soil Biol. Biochem., 31(8):1121-1134.

Huang, Y., Yu, Y. Q., Zhang, W., Sun, W. J., Liu, S. L., Jiang, J., Wu, J. S., Yu, W., Wang, Y., and Yang, Z. F. (2009). Agro-C: A biogeophysical model for simulating the carbon budget of agroecosystems. Agr. Forest Meteorol., 149(1):106-129.

Hui, D. F., Luo, Y. Q., Cheng, W. X., Coleman, J. S., Johnson, D. W., and Sims, D. A. (2001). Canopy radiation- and water-use efficiencies as affected by elevated $\left[\mathrm{CO}_{2}\right]$. Glob. Change Biol., 7(1):75-91. 
Johnson, J. M. F., Franzluebbers, A. J., Weyers, S. L., and Reicosky, D. C. (2007). Agricultural opportunities to mitigate greenhouse gas emissions. Environ. Pollut., 150(1):107-124.

Jones, C. A. and Kiniry, J. R. (1986). CERES-N Maize: a simulation model of maize growth and development. Texas A\&M University Press, College Statio, Temple, TX.

Justes, E., Denoroy, P., Gabrielle, B., and Gosse, G. (2000). Effect of crop nitrogen status and temperature on the radiation use efficiency of winter oilseed rape. Eur. J. Agron., 13(2-3):165177.

Klemedtsson, L., Jansson, P.-E., Gustafsson, D., Karlberg, L., Weslien, P., von Arnold, K., Ernfors, M., Langvall, O., and Lindroth, A. (2007). Bayesian calibration method used to elucidate carbon turnover in forest on drained organic soil. Biogeochemistry.

Kurbatova, J., Li, C., Varlagin, A., Xiao, X., and Vygodskaya, N. (2008). Modeling carbon dynamics in two adjacent spruce forests with different soil conditions in Russia. Biogeosciences, 5(4):969-980.

Lehuger, S., Gabrielle, B., Van Oijen, M., Makowski, D., Germon, J. C., Morvan, T., and Hénault, C. (2009). Bayesian calibration of the nitrous oxide emission module of an agroecosystem model. Agr. Ecosys. Environ., 133(3-4):208-222.

Lengnick, L. L. and Fox, R. H. (1994). Simulation by NCSWAP of Seasonal Nitrogen Dynamics in Corn .2. Corn Growth and Yield. Agron. J., 86(1):176-182.

Li, C. S., Frolking, S., and Harriss, R. (1994). Modeling carbon biogeochemistry in agricultural soils. Global Biogeochem. Cycles, 8(3):237-254.

Lindquist, J. L., Arkebauer, T. J., Walters, D. T., Cassman, K. G., and Dobermann, A. (2005). Maize radiation use efficiency under optimal growth conditions. Agron. J., 97(1):72-78. 
Lokupitiya, E., Denning, S., Paustian, K., Baker, I., Schaefer, K., Verma, S., Meyers, T., Bernacchi, C. J., Suyker, A., and Fischer, M. (2009). Incorporation of crop phenology in Simple Biosphere Model (SiBcrop) to improve land-atmosphere carbon exchanges from croplands. Biogeosciences, 6(6):969-986.

Metropolis, N., Rosenbluth, A. W., Rosenbluth, M. N., Teller, A. H., and Teller, E. (1953). Equation of state calculations by fast computing machines. J. Chem. Phys., 21(6):1087-1092.

Molina, J. A. E., Clapp, C. E., Schaffer, M. J., Chichester, F. W., and Larson, W. (1983). NCSOIL, a model of nitrogen and carbon transformations in doil: description, calibration and behavuoir. Soil Sci. Soc. Am. J., 45:85-91.

Molina, J. A. E., Crocker, G. J., Grace, P. R., Klir, J., Korschens, M., Poulton, P. R., and Richter, D. D. (1997). Simulating trends in soil organic carbon in long-term experiments using the NCSOIL, and NCSWAP models. Geoderma, 81(1-2):91-107.

Moureaux, C., Debacq, A., Bodson, B., Heinesch, B., and Aubinet, M. (2006). Annual net ecosystem carbon exchange by a sugar beet crop. Agr. Forest Meteorol., 139(1-2):25-39.

Nicolardot, B. and Molina, J. A. E. (1994). C and N Fluxes Between Pools of Soil Organicmatter - Model Calibration With Long-term Field Experimental-data. Soil Biol. Biochem., 26(2):245-251.

Nicolardot, B., Molina, J. A. E., and Allard, M. R. (1994). C and N fluxes Between Pools of Soil Organic-matter - Model Calibration With Long-term Incubation Data. Soil Biol. Biochem., 26(2):235-243.

Papale, D., Reichstein, M., Aubinet, M., Canfora, E., Bernhofer, C., Kutsch, W., Longdoz, B., Rambal, S., Valentini, R., Vesala, T., and Yakir, D. (2006). Towards a standardized processing 
of net ecosystem exchange measured with eddy covariance technique: algorithms and uncertainty estimation. Biogeosciences, 3(4):571-583.

Pilegaard, K., Hummelshoj, P., Jensen, N. O., and Chen, Z. (2001). Two years of continuous $\mathrm{CO}_{2}$ eddy-flux measurements over a danish beech forest. Agr. Forest Meteorol., 107(1):29-41.

Rabl, A., Benoist, A., Dron, D., Peuportier, B., Spadaro, J. V., and Zoughaib, A. (2007). How to account for $\mathrm{CO}_{2}$ emissions from biomass in an LCA. Int. J. LCA., 12(5):281-281.

Sinclair, T. R. and Muchow, R. C. (1999). Radiation use efficiency. Adv. Agron., 65:215-265.

Smith, P., Martino, D., Cai, Z., Gwary, D., Janzen, H., Kumar, P., McCarl, B., Ogle, S., O’Mara, F., Rice, C., Scholes, B., and Sirotenko, O. (2007). Agriculture. In Climate Change 2007: Mitigation. Contribution of Working Group III to the Fourth Assessment Report of the Intergovernmental Panel on Climate Change, [B. Metz, O.R. Davidson, P.R. Bosch, R. Dave, L.A. Meyer (eds)]. Cambridge University Press, Cambridge, United Kingdom and New York, NY, USA.

Svensson, M., Jansson, P. E., Gustafsson, D., Kleja, D. B., Langvall, O., and Lindroth, A. (2008). Bayesian calibration of a model describing carbon, water and heat fluxes for a Swedish boreal forest stand. Ecol. Model., 213(3-4):331-344.

Turner, D. P., Ritts, W. D., Law, B. E., Cohen, W. B., Yang, Z., Hudiburg, T., Campbell, J. L., and Duane, M. (2007). Scaling net ecosystem production and net biome production over a heterogeneous region in the western United States. Biogeosciences, 4(4):597-612.

Van Oijen, M., Rougier, J., and Smith, R. (2005). Bayesian calibration of process-based forest models: bridging the gap between models and data. Tree Physiol., 25(7):915-927. 
Veenendaal, E. M., Kolle, O., Leffelaar, P. A., Schrier-Uijl, A. P., Van Huissteden, J., Van Walsem, J., Möller, F., and Berendse, F. (2007). $\mathrm{CO}_{2}$ exchange and carbon balance in two grassland sites on eutrophic drained peat soils. Biogeosciences, 4(6):1027-1040.

Villalobos, F. J., Hall, A. J., Ritchie, J. T., and Orgaz, F. (1996). OILCROP-SUN: A development, growth, and yield model of the sunflower crop. Agron. J., 88(3):403-415.

Wallach, D. (2006). Evaluating crop models. In Wallach, D., Makowski, D., and Jones, J. W., editors, Working with dynamic crop models: evaluating, analyzing, parameterizing and using them, chapter 2. Elsevier.

Wang, J., Yu, Q., and Lee, X. (2007). Simulation of crop growth and energy and carbon dioxide fluxes at different time steps from hourly to daily. Hydrol. Process, 21(18):2474-2492.

Wang, Q. X., Masataka, W., and Zhu, O. Y. (2005). Simulation of water and carbon fluxes using BIOME-BGC model over crops in China. Agr. Forest Meteorol., 131(3-4):209-224.

Zhang, Y., Li, C., Zhou, X., and Moore, B. (2002). A simulation model linking crop growth and soil biogeochemistry for sustainable agriculture. Ecol. Model., 151(1):75-108. 


\section{List of Tables}

1 Selected characteristics of the various sites and experiments (M: Maize; WW: winter wheat; WB: winter barley; m: mustard; R: rapeseed; SF: sunflower). . . . 31

2 Description of the 16 model parameters involved in the Bayesian calibration. The prior probability distribution is a multivariate uniform distribution between bounds $\theta_{\min }$ and $\theta_{\max }$, as extracted from the above-cited literature references. The posterior parameter distributions are characterised by the mean value of the posteriors and their standard deviation (SD) . . . . . . . . . . . . 32

3 Root mean square errors (RMSEs) of daily NEP, cumulative sum of NEP and above-ground biomass based on the initial (prior) parameters values, the posterior expectancy of parameters, the maximum a posteriori parameter vector and the posterior expectancy of predictions. . . . . . . . . . . . 33

4 Root mean square errors of prediction (RMSEP) based on the posterior expectancy of parameters for daily NEP, cumulative sum of NEP over crop rotation and above-ground biomass. . . . . . . . . . . . . . . . 34

5 Carbon budgets of the crop sequences of NEU-Grignon, Auradé, Gebesee and $\mathrm{BPA}-$ Grignon. The $\mathrm{C}$ balance is broken down into net ecosystem production, harvested biomass, manure inputs. . . . . . . . . . . . . . 35 


\begin{tabular}{lllllc}
\hline Site & Experiment & Year & $\begin{array}{l}\text { Soil texture } \\
\text { class }\end{array}$ & $\begin{array}{l}\text { Sequence } \\
\text { of crops }\end{array}$ & $\begin{array}{c}\text { Number of daily } \\
\text { NEP measurements }\end{array}$ \\
\hline Grignon & NEU & $2004-2008$ & Silt Loam & M-WW-WB-m & 1627 \\
Grignon & BPA & 2002 & Silt Loam & M & 115 \\
Auradé & & $2005-2007$ & Clay Loam & R-WW-SF & 926 \\
Gebesee & & 2007 & Silty Clay Loam & WW & 310 \\
\hline
\end{tabular}

Table 1: Selected characteristics of the various sites and experiments (M: Maize; WW: winter wheat; WB: winter barley; m: mustard; R: rapeseed; SF: sunflower). 


\begin{tabular}{|c|c|c|c|c|c|c|c|c|c|c|c|}
\hline \multicolumn{4}{|c|}{ Parameter vector $\theta=\left[\theta_{1} \ldots \theta_{16}\right]$} & \multirow[b]{2}{*}{$\begin{array}{l}\text { Default } \\
\text { value }\end{array}$} & \multicolumn{3}{|r|}{$\begin{array}{l}\text { Prior probability } \\
\text { distribution }\end{array}$} & \multicolumn{4}{|c|}{$\begin{array}{c}\text { Posterior probability } \\
\text { distribution }\end{array}$} \\
\hline$\overline{\theta_{i}}$ & Symbol & Description & Unit & & $\overline{\theta_{\min }(\mathrm{i})}$ & $\theta_{\max }(\mathrm{i})$ & References & \multicolumn{2}{|c|}{ NEU-Grignon } & \multicolumn{2}{|c|}{ Auradé } \\
\hline$\theta_{1}$ & ruemaize & Radiation use efficiency of maize & $\mathrm{g} \mathrm{DM} \mathrm{MJ}^{-1}$ & 4.5 & 1.0 & 5.5 & $\begin{array}{l}\text { Sinclair and Muchow (1999); Choudhury (2001) } \\
\text { Andrade et al. (1993); Lindquist et al. (2005) }\end{array}$ & 3.0 & 0.1 & NA & $\mathrm{NA}$ \\
\hline$\theta_{3}$ & ruerap1 & $\begin{array}{l}\text { Radiation use efficiency of rapeseed } \\
\text { for vegetative phase }\end{array}$ & $\mathrm{g} \mathrm{DM} \mathrm{MJ}^{-1}$ & 2.7 & 0.8 & 4.0 & Gabrielle et al. (1998); Justes et al. (2000) & 1.83 & 0.04 & 4.75 & 1.48 \\
\hline$\theta_{4}$ & ruerap2 & $\begin{array}{l}\text { Radiation use efficiency of rapeseed } \\
\text { for reproductive phase }\end{array}$ & $\mathrm{g} \mathrm{DM} \mathrm{MJ}^{-1}$ & 2.7 & 0.8 & 3.2 & Gabrielle et al. (1998) & 2.81 & 0.17 & 1.85 & 0.17 \\
\hline$\theta_{5}$ & sflo1 & $\begin{array}{l}\text { Radiation use efficiency of sunflower } \\
\text { for vegetative phase }\end{array}$ & $\mathrm{g} \mathrm{DM} \mathrm{MJ} \mathrm{J}^{-1}$ & 1.4 & 0.7 & 3.0 & $\begin{array}{l}\text { Villalobos et al. (1996); Sinclair and Muchow (1999) } \\
\text { Albrizio and Steduto (2005) }\end{array}$ & NA & NA & 0.72 & 0.03 \\
\hline$\theta_{7}$ & prop1 & $\begin{array}{l}\text { Partitioning coefficient of total C } \\
\text { into microbial biomass pool }\end{array}$ & $\%$ & 0.015 & 0.010 & 0.030 & $\begin{array}{l}\text { Molina et al. (1983); Gabrielle et al. (2004) } \\
\text { Molina et al. (1997); Corbeels et al. (1999); Nicolardot and Molina (1994) } \\
\text { Nicolardot et al. (1994) }\end{array}$ & 0.024 & 0.006 & 0.014 & 0.003 \\
\hline$\theta_{8}$ & prop2 & $\begin{array}{l}\text { Partitioning coefficient of total } \mathrm{C} \\
\text { into humads pool }\end{array}$ & $\%$ & 0.12 & 0.10 & 0.35 & $\begin{array}{l}\text { Corbeels et al. (1999); Molina et al. (1997) } \\
\text { Nicolardot and Molina (1994); Gabrielle et al. (2002) }\end{array}$ & 0.142 & 0.040 & 0.209 & 0.060 \\
\hline$\theta_{9}$ & coef1 & $\begin{array}{l}\text { Partitioning coefficient of residue } \mathrm{C} \\
\text { into residue carbohydrate pool }\end{array}$ & $\%$ & 0.20 & 0.15 & 0.23 & Henriksen and Breland (1999) & 0.204 & 0.015 & 0.210 & 0.014 \\
\hline$\theta_{10}$ & coef2 & $\begin{array}{l}\text { Partitioning coefficient of residue } \mathrm{C} \\
\text { into residue cellulose pool }\end{array}$ & $\%$ & 0.70 & 0.65 & 0.73 & Henriksen and Breland (1999) & 0.69 & 0.03 & 0.70 & 0.01 \\
\hline$\theta_{11}$ & cf1 & $\begin{array}{l}\text { Decomposition rate of labile microbial } \\
\text { biomass pool }\end{array}$ & $d^{-1}$ & 0.332 & 0.25 & 0.50 & $\begin{array}{l}\text { Henriksen and Breland (1999); Godwin and Jone (1991) } \\
\text { Nicolardot and Molina (1994); Lengnick and Fox (1994) }\end{array}$ & 0.29 & 0.03 & 0.35 & 0.06 \\
\hline$\theta_{13}$ & cf3 & Decomposition rate of humads pool & $\mathrm{d}^{-1}$ & 0.003 & 0.002 & 0.007 & $\begin{array}{l}\text { Molina et al. (1997); Nicolardot and Molina (1994) } \\
\text { Dou and Fox (1995); Gabrielle et al. (2002) }\end{array}$ & 0.004 & 0.002 & 0.003 & 0.001 \\
\hline$\theta_{14}$ & cfres1 & $\begin{array}{l}\text { Decomposition rate of residue } \\
\text { carbohydrate pool }\end{array}$ & $d^{-1}$ & 0.20 & 0.15 & 0.80 & $\begin{array}{l}\text { Corbeels et al. (1999); Henriksen and Breland (1999) } \\
\text { Godwin and Jone (1991) }\end{array}$ & 0.29 & 0.11 & 0.61 & 0.13 \\
\hline$\theta_{15}$ & cfres2 & $\begin{array}{l}\text { Decomposition rate of residue } \\
\text { cellulose pool }\end{array}$ & $d^{-1}$ & 0.050 & 0.013 & 0.055 & $\begin{array}{l}\text { Corbeels et al. (1999); Henriksen and Breland (1999) } \\
\text { Godwin and Jone (1991); Hadas et al. (1993) }\end{array}$ & 0.045 & 0.006 & 0.022 & 0.010 \\
\hline$\theta_{16}$ & cfres3 & $\begin{array}{l}\text { Decomposition rate of residue } \\
\text { lignin pool }\end{array}$ & $\mathrm{d}^{-1}$ & 0.0090 & 0.0095 & 0.015 & Corbeels et al. (1999); Dou and Fox (1995) & 0.0099 & 0.0008 & 0.0120 & 0.0017 \\
\hline
\end{tabular}

${ }^{a}$ For wheat, net photosynthesis rate is function of ruewheat $\times \mathrm{PAR}^{0.6}$

Table 2: Description of the 16 model parameters involved in the Bayesian calibration. The prior probability distribution is a multivariate uniform distribution between bounds $\theta_{\min }$ and $\theta_{\max }$, as extracted from the above-cited literature references. The posterior parameter distributions are characterised by the mean value of the posteriors and their standard deviation (SD). 


\begin{tabular}{|c|c|c|c|c|c|c|}
\hline \multirow[t]{2}{*}{ Site } & \multirow{2}{*}{$\begin{array}{l}\text { Output } \\
\text { variables }\end{array}$} & \multirow[t]{2}{*}{ Unit } & \multicolumn{4}{|c|}{ RMSE computed with: } \\
\hline & & & $\begin{array}{c}\text { Initial parameter } \\
\text { values }\end{array}$ & $\begin{array}{l}\text { Posterior expectancy } \\
\text { of parameters }\end{array}$ & $\begin{array}{l}\text { Maximum a posteriori } \\
\text { parameter vector }\end{array}$ & $\begin{array}{l}\text { Posterior expectancy } \\
\text { of predictions }\end{array}$ \\
\hline \multirow[t]{3}{*}{ NEU-Grignon } & Daily NEP & $\mathrm{g} \mathrm{CO}_{2}-\mathrm{C} \mathrm{m}^{-2} \mathrm{~d}^{-1}$ & 2.22 & 1.90 & 1.90 & 1.89 \\
\hline & Cumulative sum of NEP & $\mathrm{g} \mathrm{CO}_{2}-\mathrm{C} \mathrm{m}^{-2}$ & 415.85 & 137.65 & 92.57 & 127.11 \\
\hline & Above-ground biomass & t DM ha ${ }^{-1}$ & 1.87 & 1.82 & 1.99 & 1.83 \\
\hline \multirow[t]{3}{*}{ Auradé } & Daily NEP & $\mathrm{g} \mathrm{CO}_{2}-\mathrm{C} \mathrm{m}^{-2} \mathrm{~d}^{-1}$ & 2.68 & 1.88 & 1.80 & 1.88 \\
\hline & Cumulative sum of NEP & $\mathrm{g} \mathrm{CO}_{2}-\mathrm{C} \mathrm{m}^{-2}$ & 217.83 & 68.68 & 83.36 & 70.03 \\
\hline & Above-ground biomass & $\mathrm{t} \mathrm{DM} \mathrm{ha}^{-1}$ & 1.84 & 1.24 & 2.93 & 1.24 \\
\hline
\end{tabular}

Table 3: Root mean square errors (RMSEs) of daily NEP, cumulative sum of NEP and aboveground biomass based on the initial (prior) parameters values, the posterior expectancy of parameters, the maximum a posteriori parameter vector and the posterior expectancy of predictions. 


\begin{tabular}{|c|c|c|c|}
\hline \multirow[t]{2}{*}{ Site } & \multicolumn{3}{|c|}{ RMSEP of: } \\
\hline & $\begin{array}{c}\text { Daily NEP } \\
\mathrm{g} \mathrm{CO}_{2}-\mathrm{C} \mathrm{m}^{-2} \mathrm{~d}^{-1}\end{array}$ & $\begin{array}{c}\text { Cumulative sum of NEP } \\
\mathrm{g} \mathrm{CO}_{2}-\mathrm{C} \mathrm{m}^{-2}\end{array}$ & $\begin{array}{c}\text { Above-ground biomass } \\
\text { t DM ha }\end{array}$ \\
\hline Gebesee & 1.55 & 90.95 & no data \\
\hline BPA-Grignon & 3.78 & 31.61 & 3.65 \\
\hline
\end{tabular}

Table 4: Root mean square errors of prediction (RMSEP) based on the posterior expectancy of parameters for daily NEP, cumulative sum of NEP over crop rotation and above-ground biomass. 


\begin{tabular}{|c|c|c|c|c|c|c|c|c|c|c|}
\hline \multirow[t]{2}{*}{ Site } & \multirow[t]{2}{*}{ Crop } & \multicolumn{2}{|l|}{ Time period } & \multicolumn{2}{|c|}{$\begin{array}{l}\text { Net ecosystem production } \\
\left(\mathrm{kg} \mathrm{C} \mathrm{ha}^{-} 1\right)\end{array}$} & \multicolumn{2}{|c|}{$\begin{array}{c}\text { Harvested biomass } \\
\left(\mathrm{kg} \mathrm{DM} \mathrm{ha}^{-} 1\right)\end{array}$} & \multirow[t]{2}{*}{$\begin{array}{l}\text { Manure } \\
\left(\mathrm{kg} \mathrm{C} \mathrm{ha-1)}^{-}\right)\end{array}$} & \multicolumn{2}{|c|}{$\begin{array}{l}\text { Net biome production } \\
\left(\mathrm{kg} \mathrm{C} \mathrm{ha}^{-} 1\right)\end{array}$} \\
\hline & & Start & End & Modelled & Observed & Modelled & Observed & & Modelled & Observed \\
\hline \multirow[t]{7}{*}{ NEU-Grignon } & Mustard & 2004-09-01 & $2005-05-08$ & -822 & -456 & & & 988 & 166 & 532 \\
\hline & Maize & 2005-05-09 & $2005-10-15$ & 5515 & 5139 & -13510 & -15470 & & 111 & -1049 \\
\hline & Winter wheat & 2005-10-16 & 2006-10-05 & 3510 & 2621 & $\begin{array}{l}-7597 \\
(-5859)\end{array}$ & $\begin{array}{l}-7500 \\
(-8430)\end{array}$ & & -1872 & -3751 \\
\hline & Barley & 2006-10-06 & $2007-10-21$ & 4485 & 5377 & $\begin{array}{l}-8630 \\
(-3632)\end{array}$ & $\begin{array}{l}-8200 \\
(-3640)\end{array}$ & & -419 & 641 \\
\hline & Mustard & $2007-10-22$ & $2008-04-26$ & 632 & 875 & & & 1763 & 2395 & 2638 \\
\hline & Maize & 2008-04-27 & $2008-10-14$ & 6627 & 8005 & -13730 & -20470 & & 1135 & -183 \\
\hline & Rotation & 2005-05-09 & $2008-04-26$ & 14143 & 14012 & & & & 215 & -1521 \\
\hline \multirow[t]{4}{*}{ Auradé } & Rapeseed & 2005-03-18 & $2005-10-24$ & 2745 & 2504 & -3768 & -5300 & & 1237 & 384 \\
\hline & Winter wheat & $2005-10-25$ & 2007-04-09 & 2816 & 2088 & -6378 & -6000 & & 265 & -312 \\
\hline & Sunflower & 2007-04-10 & 2007-09-29 & 1611 & 1311 & -2116 & -2200 & & 765 & 431 \\
\hline & Rotation & 2005-03-18 & 2007-09-29 & 7172 & 5903 & & & & 2267 & 503 \\
\hline Gebesee & Winter wheat & 2007-01-01 & $2007-10-05$ & 2622 & 1134 & -7165 & -4700 & 4460 & 4216 & 3714 \\
\hline BPA-Grignon & Maize & 2002-06-15 & $2002-10-07$ & 6476 & 6643 & -16130 & -23040 & & 24 & -2573 \\
\hline
\end{tabular}

Table 5: Carbon budgets of the crop sequences of NEU-Grignon, Auradé, Gebesee and BPAGrignon. The $\mathrm{C}$ balance is broken down into net ecosystem production, harvested biomass, manure inputs. 


\section{List of Figures}

1 Schematic of $\mathrm{C}$ fluxes (solid arrows) and $\mathrm{N}$ flows (dashed arrows) within the CERES-EGC model. . . . . . . . . . . . . . . . . . 37

2 Time course of simulated (black line) and observed (grey symbols) of net ecosystem production (NEP), on a daily time scale $(\mathrm{a}, \mathrm{d})$ or cumulated for each growing season (c,f), and scatter plot of simulated versus measured NEP (b,e). The top graphs pertain to the NEU-Grignon experiment $(\mathrm{a}, \mathrm{b}, \mathrm{c})$, the bottom one to the Auradé experiment (d,e,f). Simulation lines correspond to the posterior expectancies of simulations, and the crop cycles are represented with the following letters: B: barley, m: mustard, M: maize, WW: winter wheat, R: rapeseed and SF: sunflower. . . . . . . . . . . . . . . . .

3 Simulations (black line) and observations (grey points) of above-ground (ABG) crop biomass $(\mathrm{a}, \mathrm{c})$ and simulated versus measured ABG biomass $(\mathrm{b}, \mathrm{d})$ for the crop sequence of Grignon site (a,b) and Auradé site (c,d). Simulation lines correspond to the posterior expectancies of simulations, and the crop cycles are represented with the following letters: B: barley, m: mustard, M: maize, WW: winter wheat, R: rapeseed and SF: sunflower.

4 Simulations (black line) and observations (grey points) of daily net ecosystem production (NEP), simulated versus measured NEP and simulations (black line) and observations (grey points) of cumulative sum of NEP for the wheat crop cycle of Gebesee site $(a, b, c)$ and the maize crop cycle of BPA-Grignon experiment

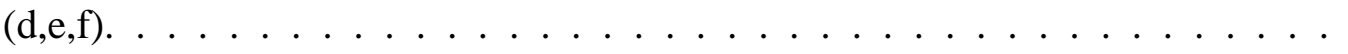

5 Simulations with calibrated parameter values (solid line) and initial parameter values (dashed line) and observations (grey points) of above-ground (ABG) crop biomass (a). Simulated versus measured ABG biomass for simulations with calibrated parameters (empty points) and initial parameter values (full points) for the maize crop cycle of BPA-Grignon site (b, the measurement of 7 Oct. 2002 was removed of the data set). Simulated lines with calibrated parameters are the posterior expectancies of simulations. Carbon balances of the crop sequences at Grignon, Auradé and Gebesee based on simulations with the calibrated model. Net ecosystem production (NEP) is broken down into net primary production (NPP) and heterotrophic soil respiration (Rs). The crops of the different rotations are winter barley (B), mustard (m), maize (M), winter wheat (WW), rapeseed (R) and sunflower (SF). The two digits after each crop abbreviation denotes the year of harvest or the year of incorporation in soil for the mustard used as a catch crop. . . . . . . . . . . . . . . 


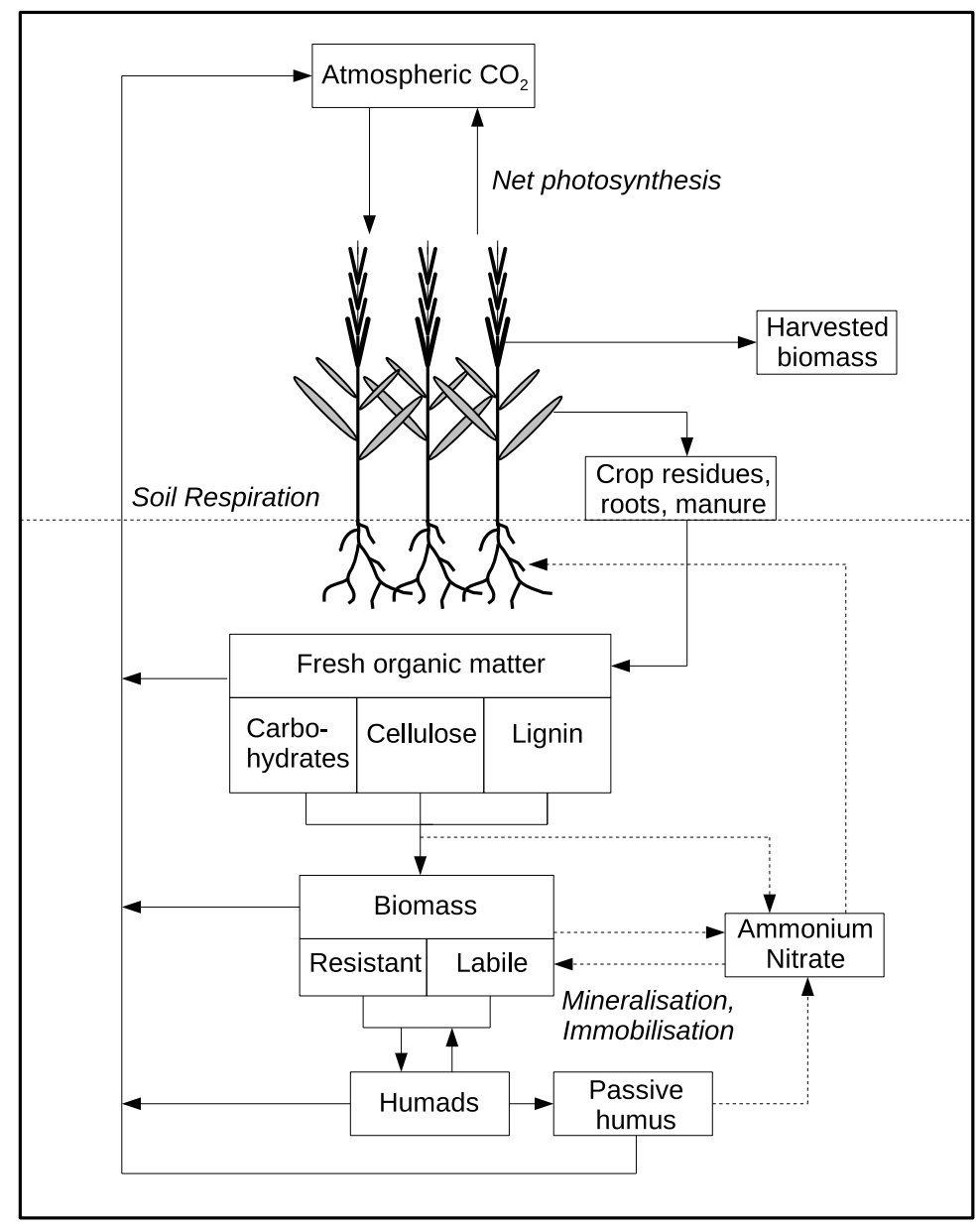

Figure 1: Schematic of $\mathrm{C}$ fluxes (solid arrows) and $\mathrm{N}$ flows (dashed arrows) within the CERESEGC model. 

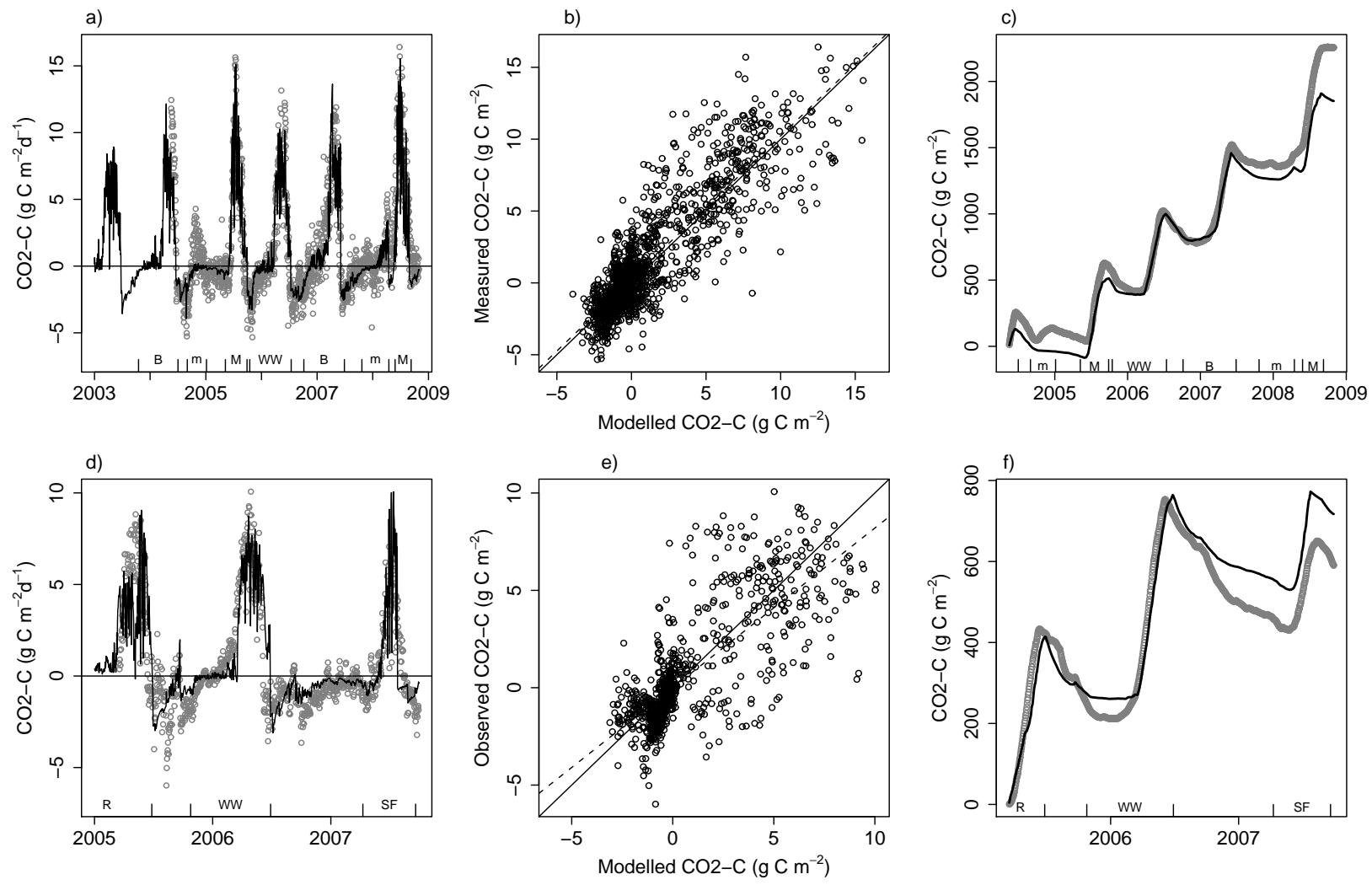

Figure 2: Time course of simulated (black line) and observed (grey symbols) of net ecosystem production (NEP), on a daily time scale $(\mathrm{a}, \mathrm{d})$ or cumulated for each growing season (c,f), and scatter plot of simulated versus measured $\operatorname{NEP}(b, e)$. The top graphs pertain to the NEU-Grignon experiment $(\mathrm{a}, \mathrm{b}, \mathrm{c})$, the bottom one to the Auradé experiment $(\mathrm{d}, \mathrm{e}, \mathrm{f})$. Simulation lines correspond to the posterior expectancies of simulations, and the crop cycles are represented with the following letters: B: barley, m: mustard, M: maize, WW: winter wheat, R: rapeseed and SF: sunflower. 

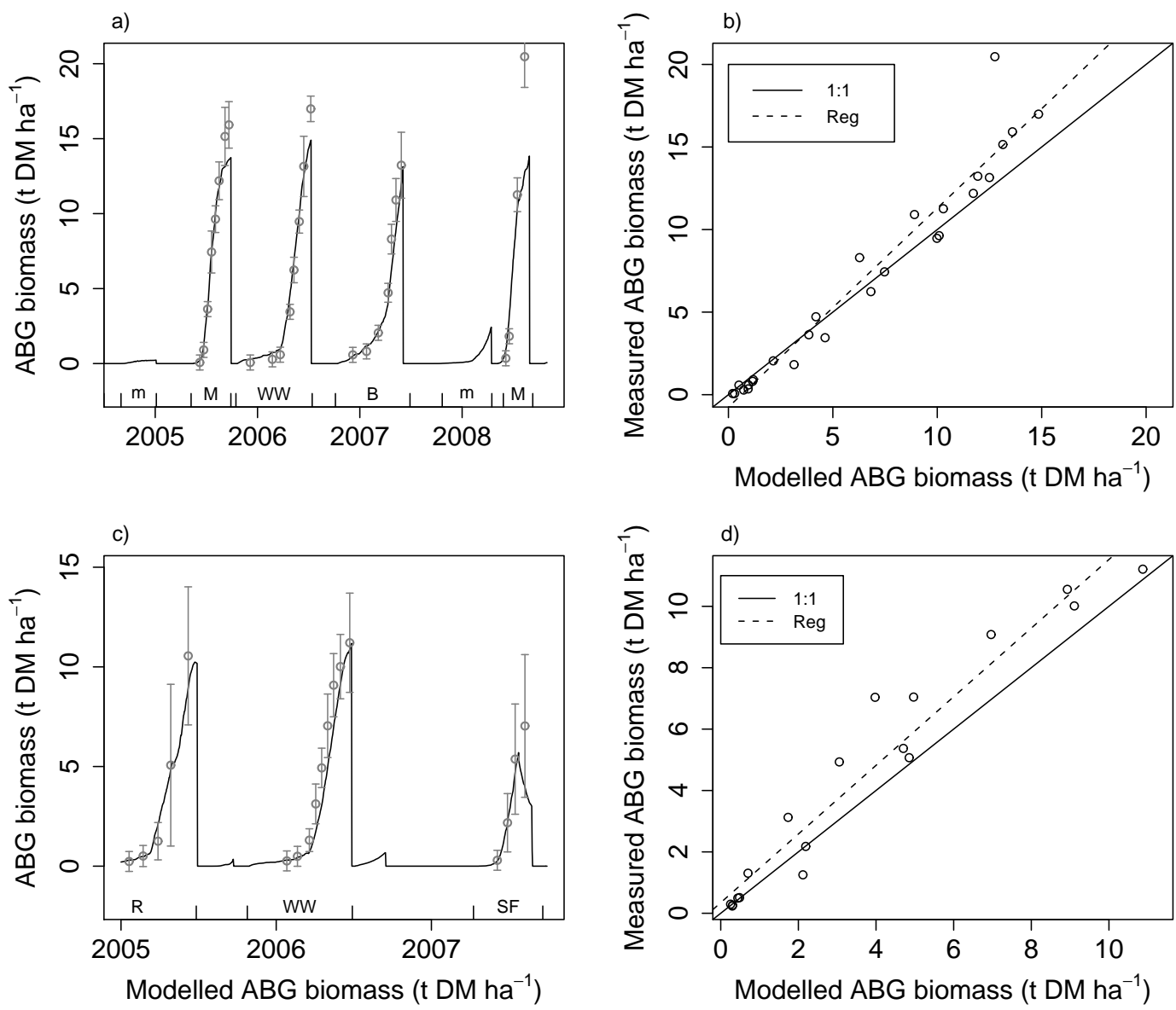

Figure 3: Simulations (black line) and observations (grey points) of above-ground (ABG) crop biomass (a,c) and simulated versus measured ABG biomass (b,d) for the crop sequence of Grignon site $(a, b)$ and Auradé site (c,d). Simulation lines correspond to the posterior expectancies of simulations, and the crop cycles are represented with the following letters: B: barley, m: mustard, M: maize, WW: winter wheat, R: rapeseed and SF: sunflower. 

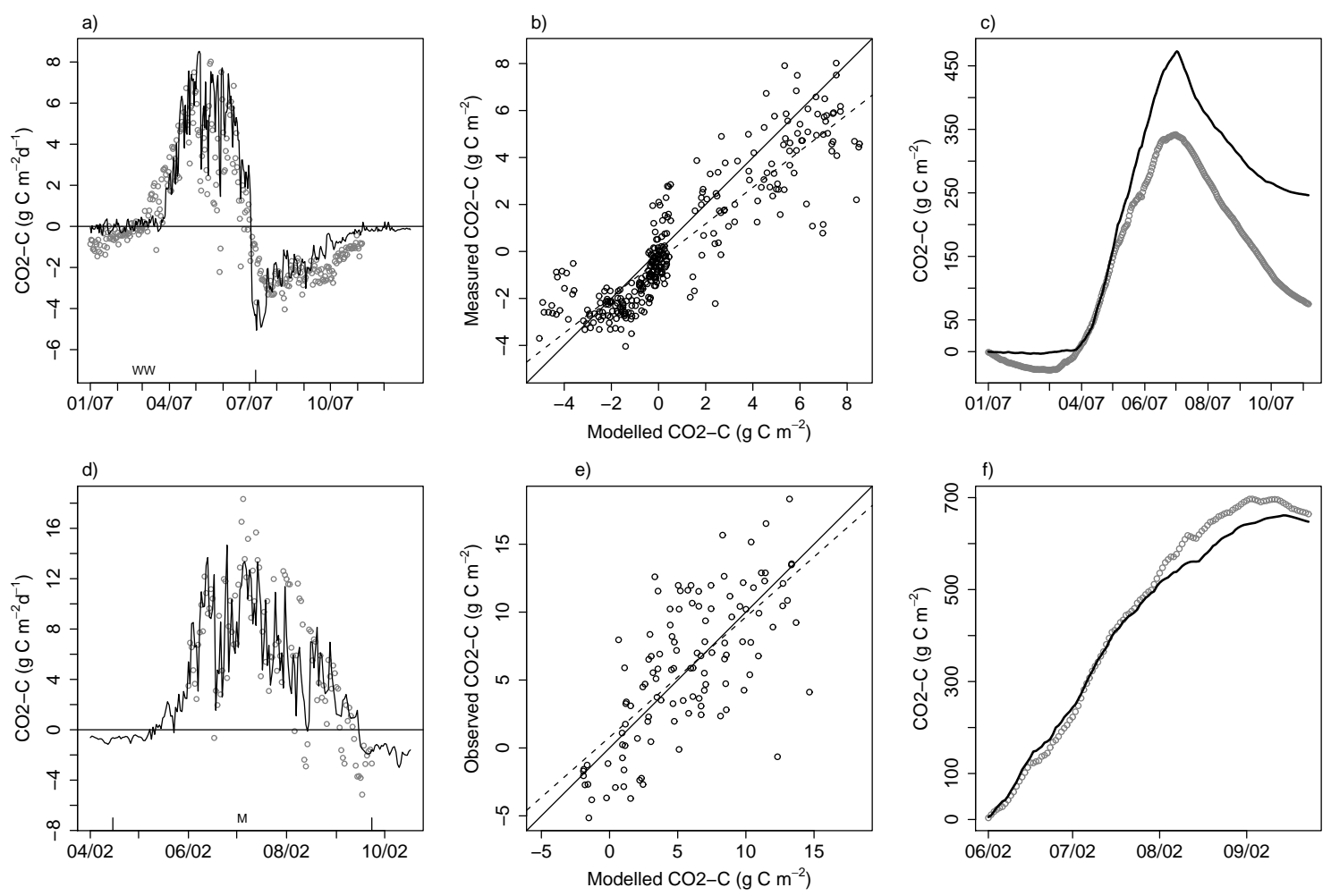

Figure 4: Simulations (black line) and observations (grey points) of daily net ecosystem production (NEP), simulated versus measured NEP and simulations (black line) and observations (grey points) of cumulative sum of NEP for the wheat crop cycle of Gebesee site $(a, b, c)$ and the maize crop cycle of BPA-Grignon experiment $(\mathrm{d}, \mathrm{e}, \mathrm{f})$. 

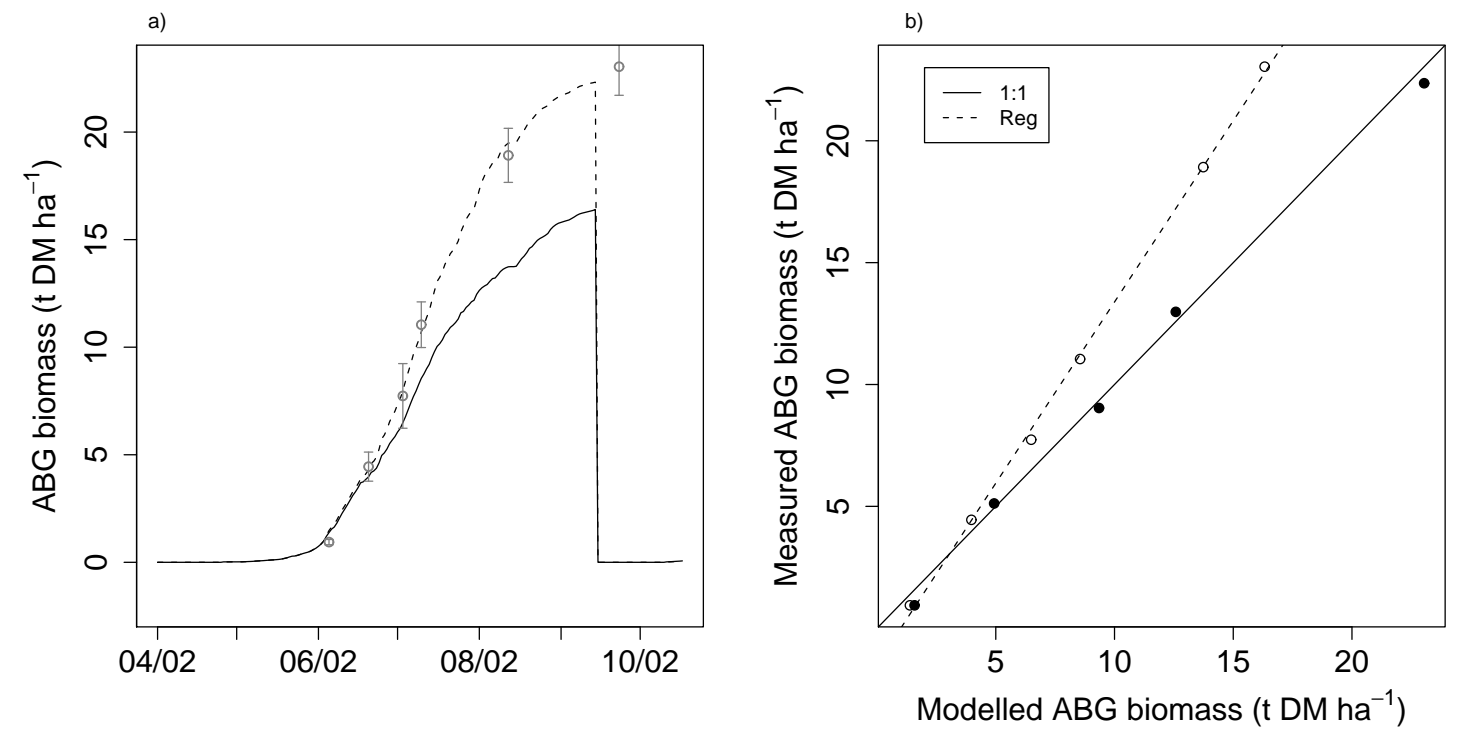

Figure 5: Simulations with calibrated parameter values (solid line) and initial parameter values (dashed line) and observations (grey points) of above-ground (ABG) crop biomass (a). Simulated versus measured $\mathrm{ABG}$ biomass for simulations with calibrated parameters (empty points) and initial parameter values (full points) for the maize crop cycle of BPA-Grignon site (b, the measurement of 7 Oct. 2002 was removed of the data set). Simulated lines with calibrated parameters are the posterior expectancies of simulations. 

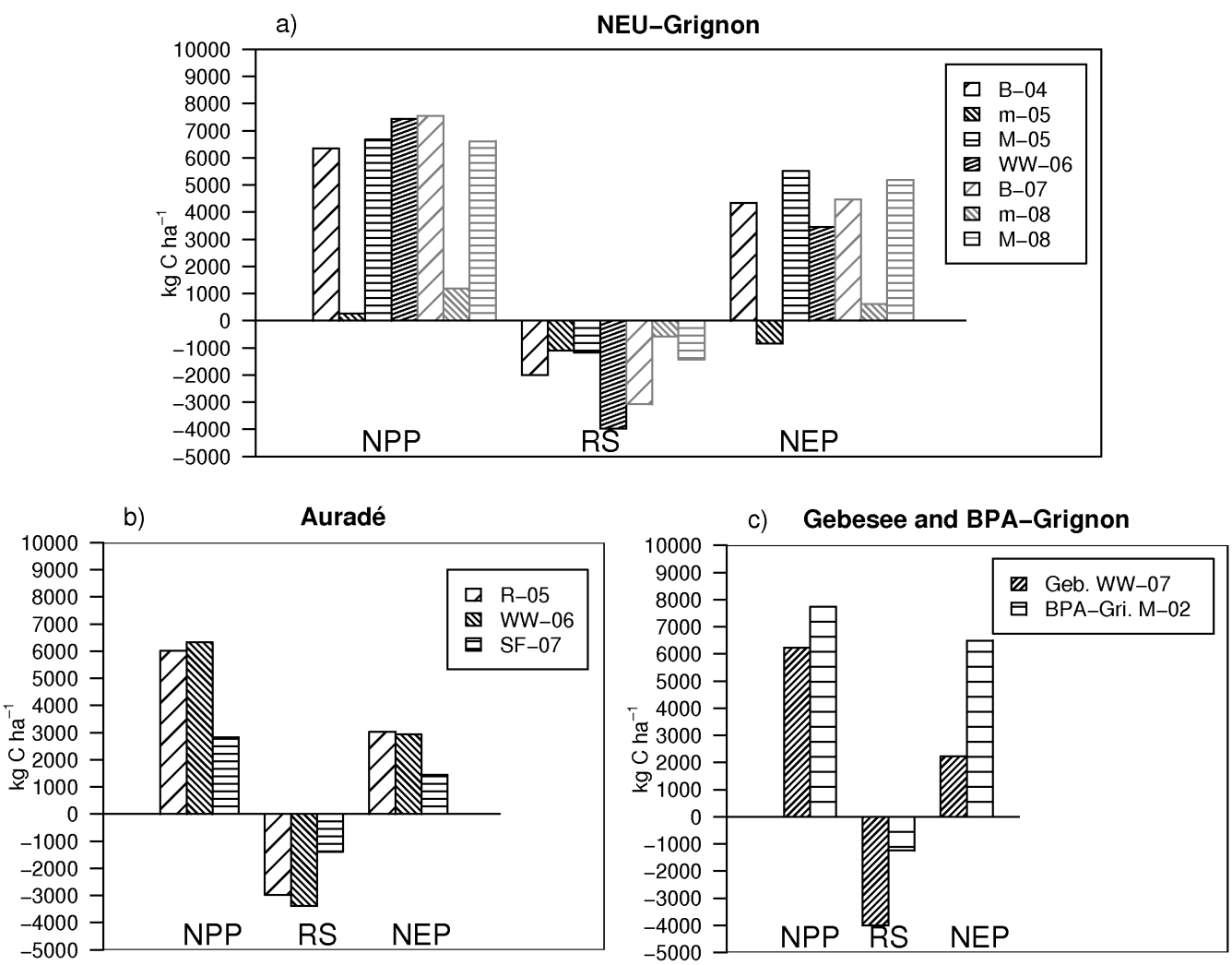

Figure 6: Carbon balances of the crop sequences at Grignon, Auradé and Gebesee based on simulations with the calibrated model. Net ecosystem production (NEP) is broken down into net primary production (NPP) and heterotrophic soil respiration (Rs). The crops of the different rotations are winter barley $(\mathrm{B})$, mustard $(\mathrm{m})$, maize $(\mathrm{M})$, winter wheat $(\mathrm{WW})$, rapeseed $(\mathrm{R})$ and sunflower (SF). The two digits after each crop abbreviation denotes the year of harvest or the year of incorporation in soil for the mustard used as a catch crop. 